A growing opportunity: Alberta's forest resources 
Digitized by the Internet Archive in 2016 
A growing opportunity: Alberta's forest resources 


\section{Alberta's forests}

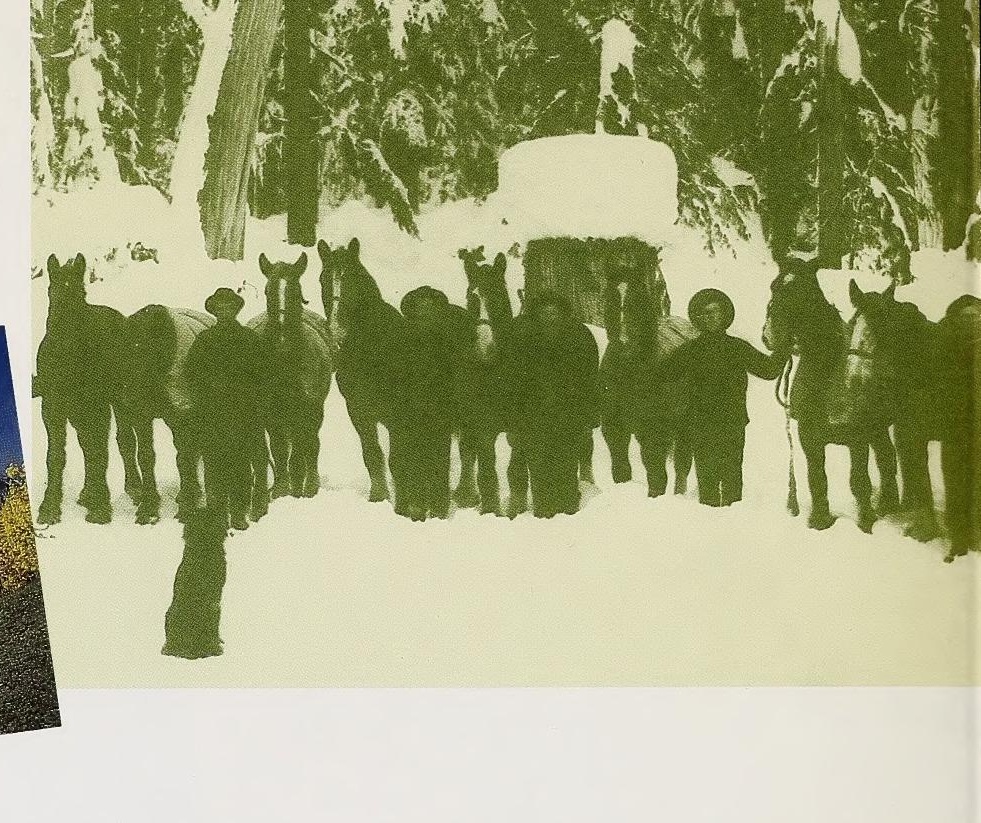

Ask anyone in Canada where Alberta

Forests provide Alberta's

recreation and hospitality

industries with relatively

untapped tourist

opportunities.

is and, nine times out of ten, they'll geographic sense, this is true, but many people - Albertans included would be startled to discover that almost two-thirds of the province is covered by forest. Most of this say it's part of the prairies. In a strict forested area is public land.

This land is used for many activities timber harvesting, trapping, grazing, exploration for oil and gas, coal mining and many forms of recreation, such as hunting, fishing, hiking, camping, birdwatching, photography and cross country skiing.

The resources found on or beneath these public lands are also managed by the government. They include minerals, timber, water, fisheries and wildlife.
From Wood Buffalo National Park in the north, down along the foothills skirting the Rocky Mountains to the United States border in the south, there are 360,000 square kilometres of forest land in Alberta. Our forests cover an area larger than those of Sweden.

Most of Alberta's forests are dominated by lodgepole pine, white and black spruce, and two species of poplar. Lodgepole pine, white spruce and aspen (poplar) account for most of Alberta's total timber production.

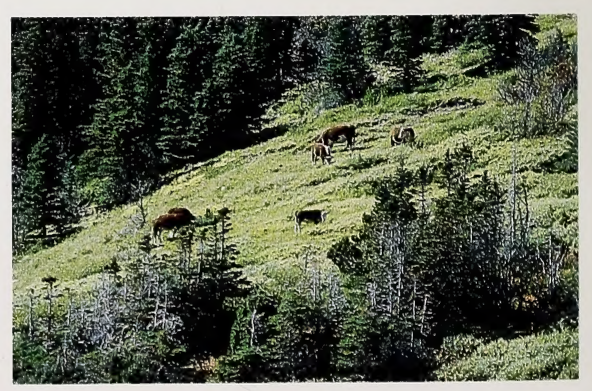


Based on the most recent forest inventory, Alberta has more than two billion cubic metres of coniferous and deciduous timber.

In 1989 less than one-half of one per cent of this renewable forest resource was used to provide approximately one billion dollars in forest products sales. Alberta's forest industry produces lumber, posts and rails, pulp, paper, and wood chips. In order to harvest the forest, companies must submit annual operating plans for provincial approval and assume extensive responsibilities in forest management and renewal.

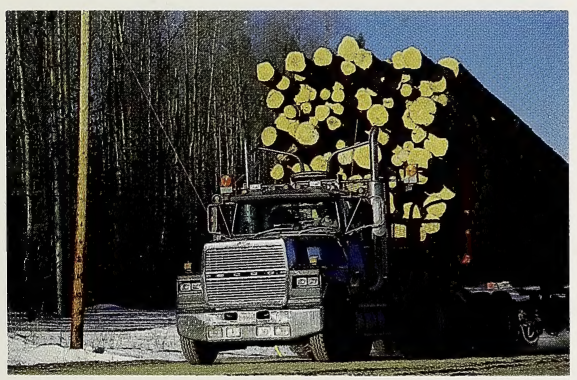

While softwood timber dominates the industry, new applications have increased the demand for native hardwoods, especially the aspen (or poplar) found extensively in northern Alberta. A number of companies are now producing hardwood pulp and structural panel board.

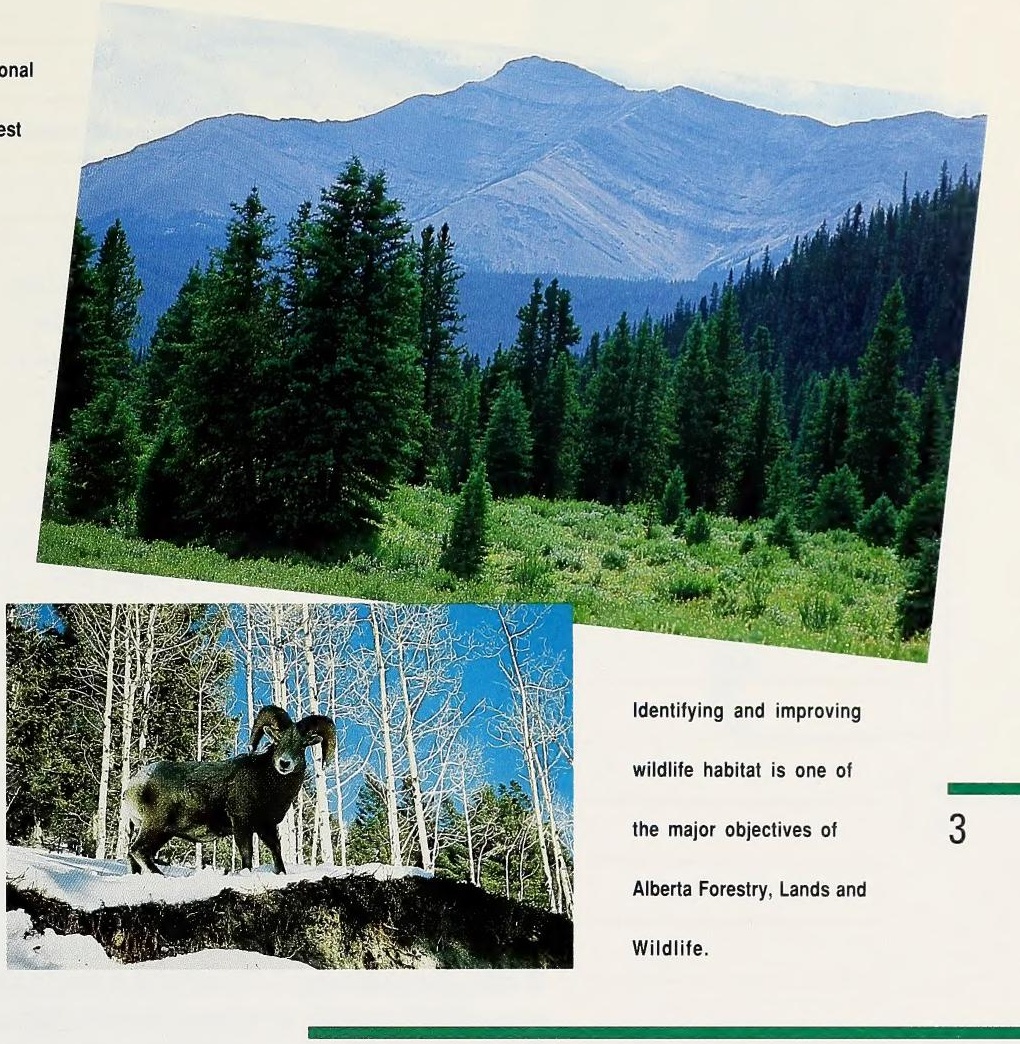

Alberta's road and rail

networks ensure efficient

transportation of forest

products from forest to mill

to end-user.
The role of the department

Alberta Forestry, Lands and Wildlife manages Alberta's renewable resources. Departmental responsibilities include resource planning and management, surveying, mapping and aerial photography, fire protection and administration of legislation regulating land use. $\Delta$ The Department's "integrated use" concept encourages the growth of the forest products industry while ensuring Alberta's forested public lands continue to provide fish and wildlife habitat, vital watersheds, grazing lands, non-renewable resource development sites and a variety of outdoor recreation and tourism opportunities. $\Delta$ The province's integrated resource planning process is designed to identify land use needs and resolve potential conflicts among competing interests for Alberta's public lands. The process assists in protecting sensitive environmental areas while planning for developments that may involve timber harvesting, resort projects, or agricultural expansion. $\Delta$ 


\section{Getting involved}

A key factor in balancing sustainable economic development with a sustainable forest resource is the involvement of the citizens of Alberta. $\Delta$ Integrated resource management is a complex responsibility requiring an understanding of all of the activities competing for use of Alberta's forest lands. $\triangle$ Alberta's policy regarding the use of forest resources is that the environment of land, water, vegetation and wildlife are managed as an ecosystem, and not as separate elements. Although competing uses are often viewed individually, effective management of the resource must consider the many interrelationships with the environment. $\Delta$ In the eastern slopes of the Rocky Mountains, for example, the province has set the following goals for the management of the natural resources found in that region:

Water Management To ensure a continuous, reliable supply of clean water to meet the needs of Albertans and interprovincial users now and in the future.

Protection of valuable water

resources is a part of

Alberta's overall forest

management.

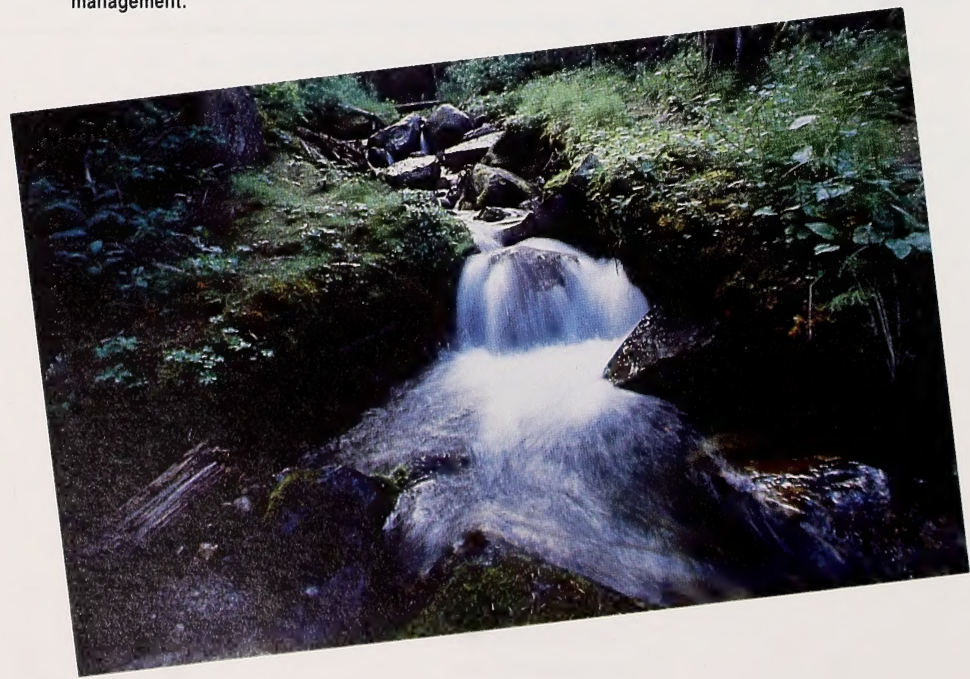

Fisheries To provide a variety of outdoor recreational opportunities based on fisheries resources for the benefit and enjoyment of Albertans.

Recreation To provide both private and public recreation opportunities that will meet the needs of Albertans and also enhance the vacation experiences of visitors to the province.

Timber To provide an optimal, continuous contribution to the economy by the forestbased industries consistent with sound environmental practices recognizing other uses of the forest.

Rangeland To provide a properly managed forage base on rangelands for use by wildlife and domestic livestock.

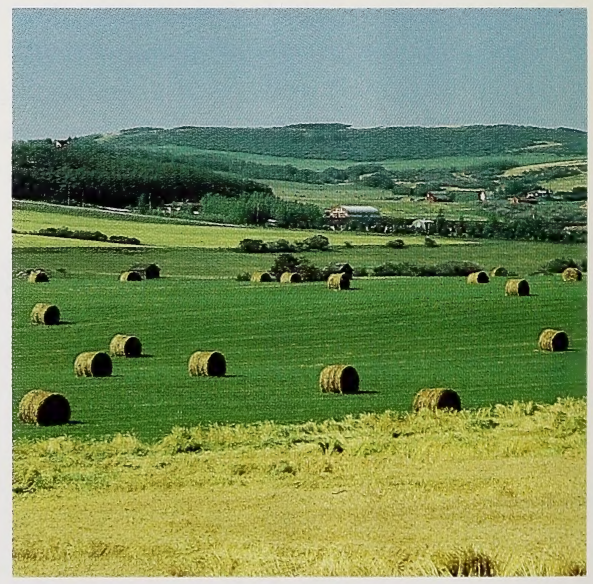

Agriculture To encourage the optimal development of the renewable resources for the production, processing and marketing of agricultural products for expanding domestic and export markets.

Tourism To encourage the provision of a diverse range of private and public sector tourism facilities, attractions, accommodations and services capable of meeting increasing demands for leisure and business-related opportunities. 


\section{Mineral Resources To encourage}

exploration and development of all mineral resources to meet the needs of Albertans now and in the future.

\section{Cultural and Ecological Resources}

To ensure that significant features of archaeological, ecological or historical value are identified, protected and managed for scientific, educational and recreational benefits.

In the foothills of the Rockies and throughout the province, achieving harmony among these activities and related development opportunities is a vital and continuous task. Integrated resource management ensures a balanced use of public lands and resources important to the economic strength and quality of life in Alberta. $\Delta$ Public involvement and a team approach are the keys to successful integrated resource planning. It allows resource specialists and interested parties to work together. Those involved must be willing to discuss all resource concerns and re-evaluate their own positions. $\Delta$ More citizens are taking part in the planning process. Government departments are considering a wide range of opinions and recommendations from people with a keen sense of how important the forests are to us as people and as a province.
Alberta's forests cover

approximately 360,000

square kilometres.

\section{Taking stock}

Alberta is one of the few regions in Canada with a surplus of commercially valuable softwood timber, primarily lodgepole pine and white spruce, and hardwood timber, mostly aspen (poplar). $\Delta$ According to the most recent forest inventory, the total gross merchantable wood volume on Alberta's productive forest land is over two billion cubic metres. $\Delta$ High quality maps illustrate species composition, heights, density and ages of various forest stands in Alberta. The maps and inventory information also assist in planning and meeting more specific needs such as selecting the best routes for roads, identifying wildlife habitat, and choosing stands that should be harvested. $\Delta \mathrm{A}$ data bank tracks adjustments to the resource from timber harvesting, forest fires, or other causes so that the inventory and mapping remain accurate and current. $A$

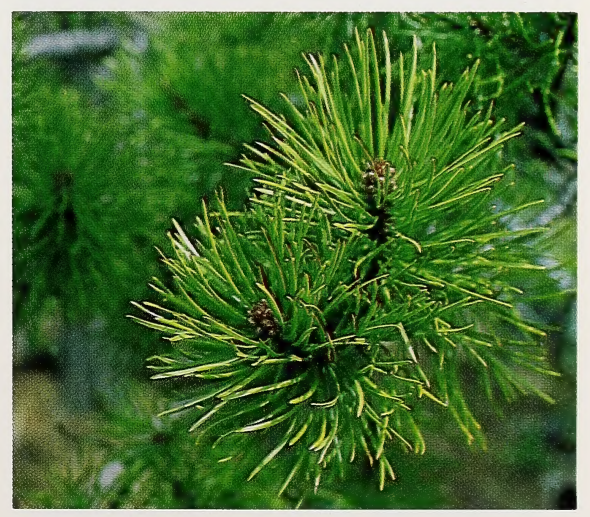




\section{Tourism in the Forest}

Tourism is Alberta's third largest employment and revenue generating industry. Many of the province's most popular tourist attractions are its wilderness lakes, mountains and forests. Alberta's unspoiled natural beauty provides foreign visitors with opportunities such as sightseeing tours and wilderness adventure challenges. Outdoor activities such as camping, hiking, hunting, fishing, golf, overnight trail rides, skiing and mountaineering are promoted. $\Delta$ Albertans generate about half of the province's tourism revenue - much of it in return visits to the wilderness recreation areas in Banff, Jasper and Kananaskis Country. $\Delta$ The increase in tourists visiting
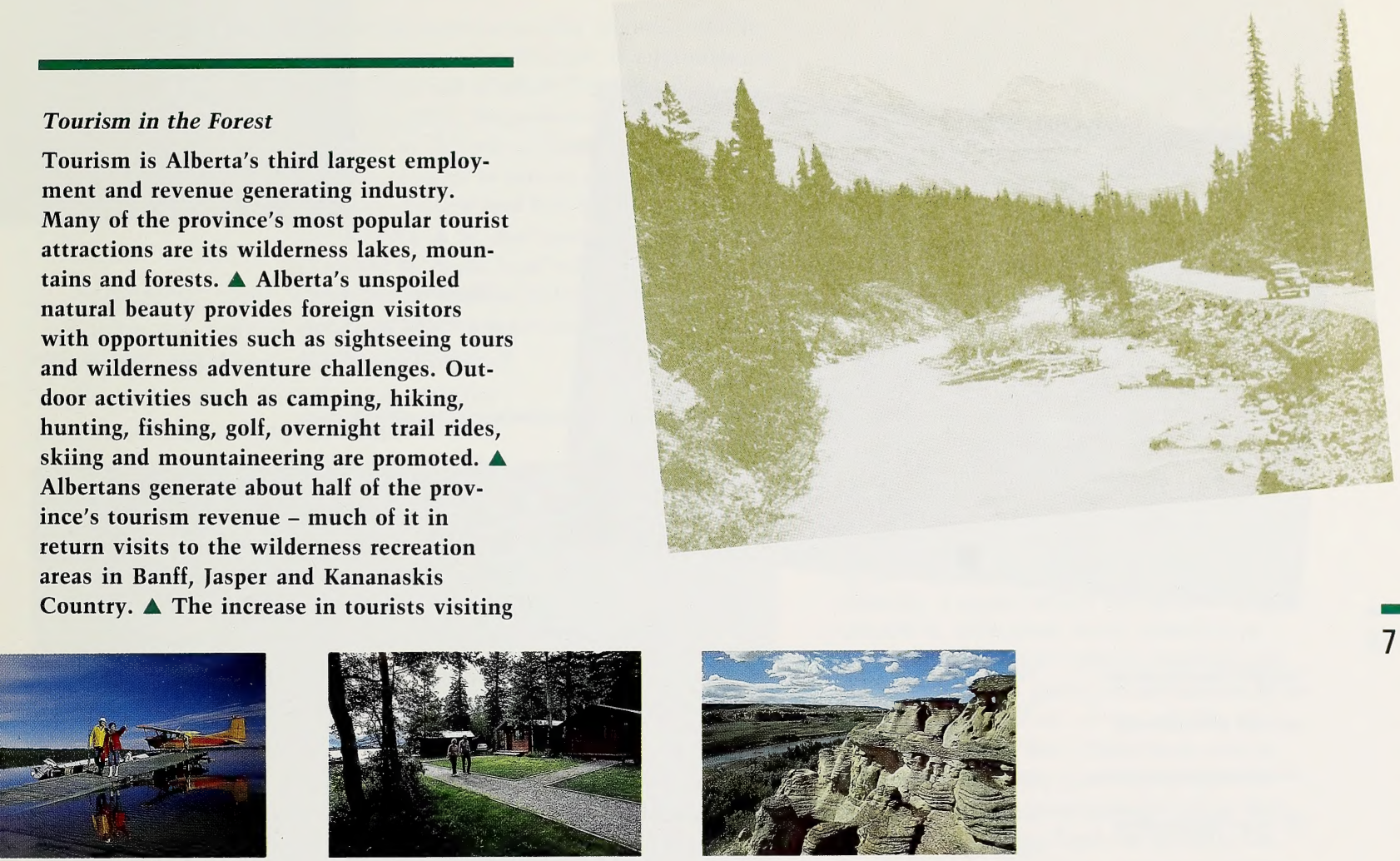

our forests demands more roads, campgrounds, resorts, and water and power services. The way people travel to an area and the services available to them upon arrival may have a significant impact on the forest environment. $\Delta$ The provincial government and the Alberta tourism industry have become increasingly interested in promoting the use of forested lands through such private sector developments as guest ranches, commercial campgrounds and cross-country ski lodges. $\Delta$ The government, tourism industry, and the communities and individuals most affected by increasing tourism activities are working together to determine how good forest management can best continue to contribute to, and benefit from, this growing tourism opportunity. $\triangle$

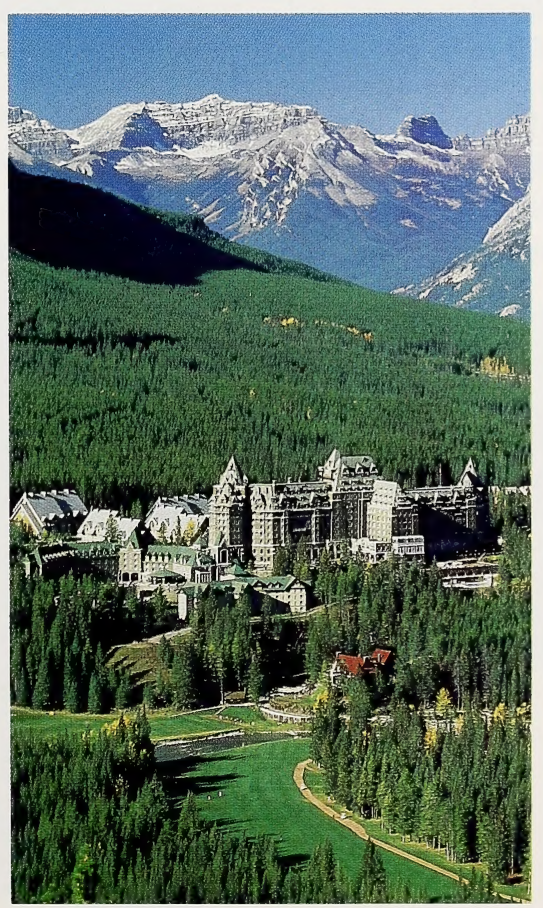




\section{Wildlife in Alberta}

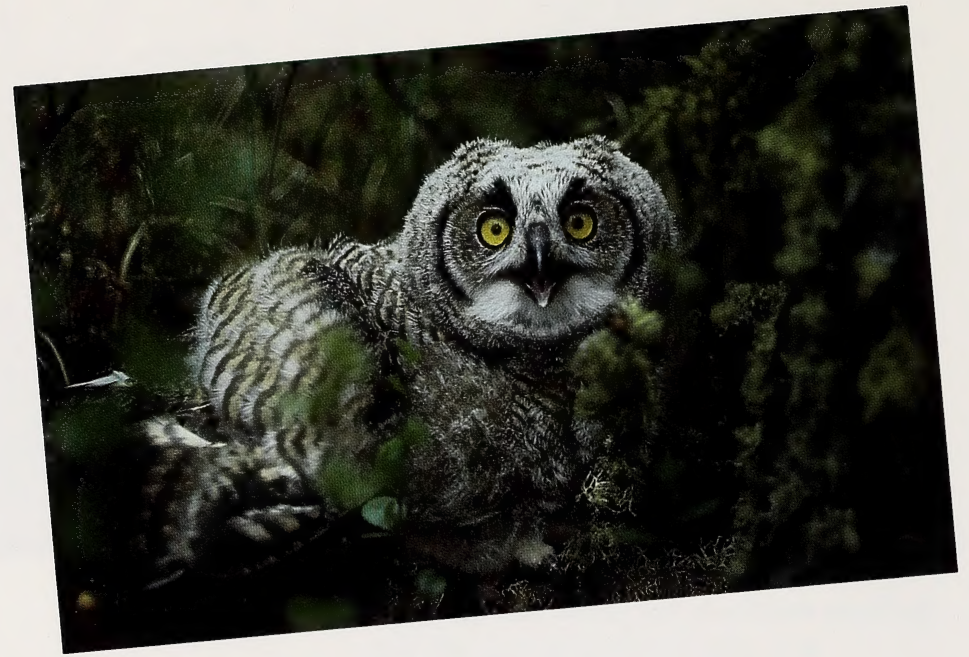

Integrated resource manage-

ment and strict guidelines

on timber harvesting protect

and often improve wildlife

habitat.
Wildlife need space, shelter, abundant food and clean water. As a forest grows older, the trees begin to close in, blocking the sunlight. The grasses and plants eaten by "open forest" species such as elk, deer, moose and other animals become scarce, while "mature forest" species like caribou and pine marten begin to thrive.

Alberta Forestry, Lands and Wildlife works to protect the needs of wildlife through proper management of forests.

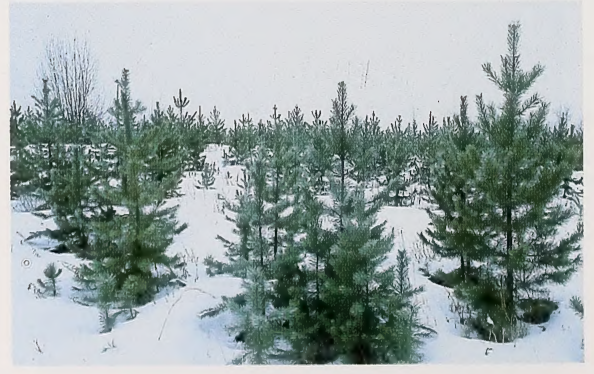

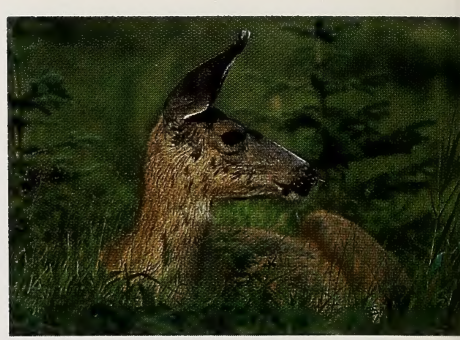

Forests are often more productive for wildlife after timber harvesting operations open new areas. Some wildlife populations increase, partly due to forest managers and biologists identifying and protecting known calving areas and animal migration routes.

Small blocks of timber, harvested selectively or over a number of years, can gradually open portions of the forest to native grasses and shrubs and provide food for a variety of animals.

Forest cover is maintained for shelter or protection from predators. In some areas, standing dead trees are left for use by a variety of bird species.

Alberta's forest management preserves a variety of vegetation important to wildlife.

Alberta's trees are a resource

whose renewal requires

careful management and

effective reforestation

techniques. 
The province's forests are

home and refuge for hundreds

of species of animals.

Species such as deer and elk

need open areas in the forest

\section{Buck for Wildlife}

One of the most successful Alberta wildlife programs, Buck for Wildlife, is administered by the Fish and Wildlife Trust Fund. $A$ Started in 1973, the program uses levies attached to the sale of hunting and fishing licenses, as well as private donations, to improve wildlife and fish habitat throughout Alberta. A In most cases, money spent is matched by funds from other government departments such as Alberta Environment and from private organizations such as Ducks Unlimited. A
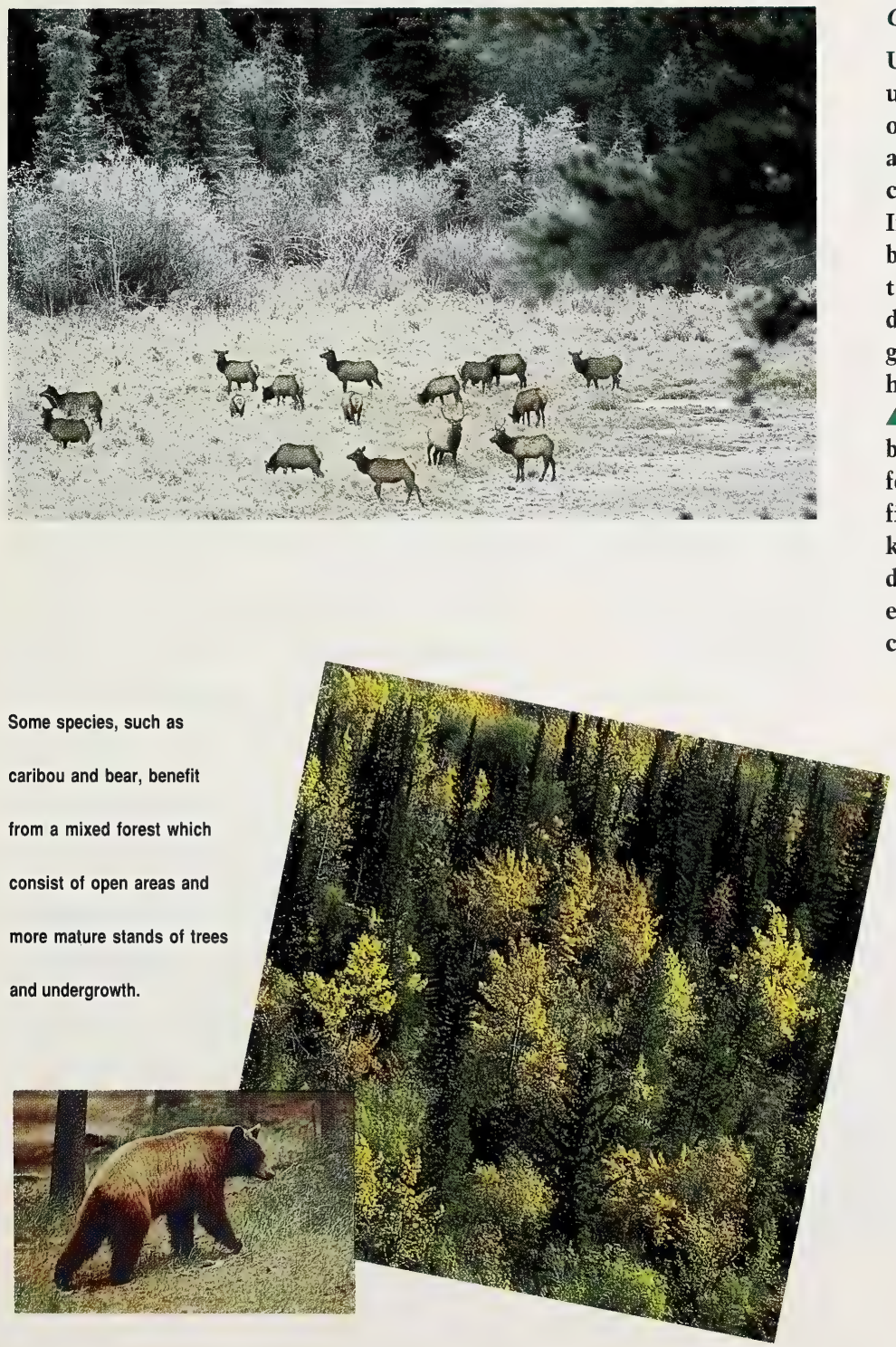

\section{Controlled burning}

Unchecked forest fires ignited by lightning used to be part of a natural cycle that opened up overgrown areas for large game animals. Today, trained firefighters quickly control or extinguish these wildfires. $A$ In the past, Alberta's natives used limited burns during wet spring conditions to maintain good populations of the wildlife they depended on for food. These fires created grazing areas for big game and improved habitat for small mammals and game birds. $\Delta$ In today's forest, Buck for Wildlife has been active in financing prescribed burns for the same reasons, during periods of low fire hazard. Firebreaks are put in place to keep the blaze from spreading outside the designated zone. $\Delta$ Clearing timber through either harvesting or controlled burning has created new range for big game animals. $\Delta$ 


\section{Getting the jump on wildfires}

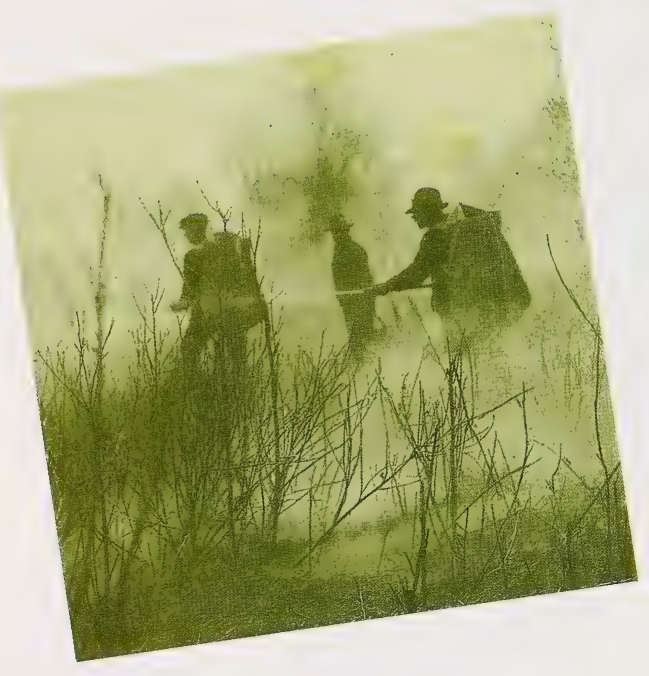

Forest fire protection began

in Alberta in the 1930 s.

Alberta has one of the best forest protection programs in North America and it safeguards more than just an economic asset of the province!

Alberta's forests contain more than two billion cubic metres of standing timber. While that represents a lot of renewable resource dollars, there are many additional benefits as well.

A forest is a home for animals, a source of recreation, and a major factor in watershed management and erosion control.

Alberta's immensely valuable forest is also vulnerable to such potentially harmful forces as wildfire, insects and disease. Safeguarding the forests is the responsibility of dedicated foresters, rangers, technicians, scientists, pilots, administrators, firefighters and others who make use of the forest resource for business or pleasure.

Fire is the most visible and dramatic threat to the forest resource. The destructive potential of flames in dry timber is difficult to imagine. A carelessly dropped match or a bolt of lightning can start a wildfire and wipe out thousands of hectares of valuable timber, wildlife habitat or scenic recreational areas in a matter of hours.

\section{Alberta's approach to minimizing} its forest fire losses centres on a combination of active prevention, immediate detection and early suppression. As roughly half of all forest fires are caused by human activity, half of all forest fires should be preventable. An on-going public education campaign includes a variety of initiatives. There are radio and television public service announcements and pamphlets and brochures, urging the public to handle campfires safely. 


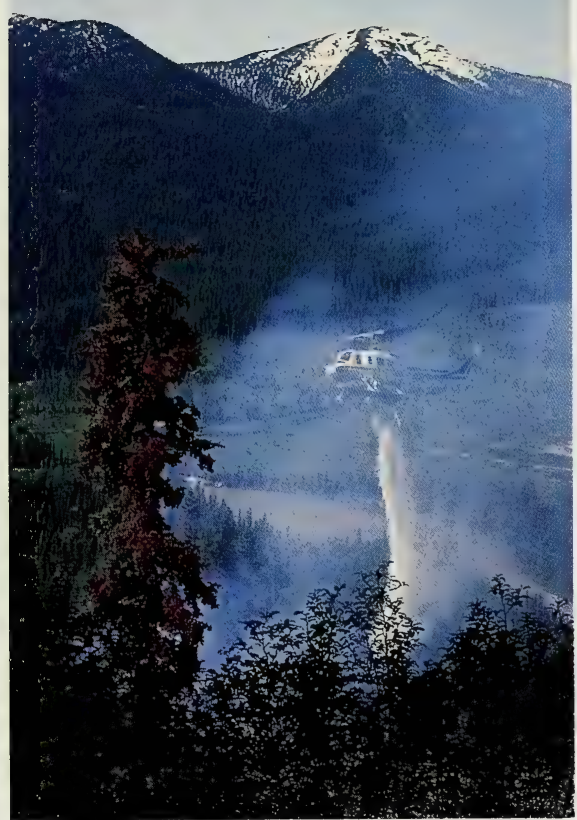

The familiar fire tower remains the front line of defense for fire detection in Alberta. A network of manned lookout sites provides intensive surveillance of the forest during the fire season.

Lending support to the lookouts are aircraft patrols and high-tech innovations such as the infra-red heat scanner and the electronic lightning locator system. The lightning detection equipment is designed to plot and record the sites of lightning strikes the instant they occur anywhere in the province.

Once a fire has been detected, the key to limiting its damage is early and effective suppression. Firefighters and equipment are strategically placed in areas of extreme fire hazard.

Helicopters rush highly trained fire crews to the scene within minutes of detection.
Elementary students and

teachers use classroom

kits with posters, activity

books, buttons and other

learning resources.

At the peak of the fire season,

up to 100 helicopters and

500 firefighters may be

standing by to "action"

reported wildfires.

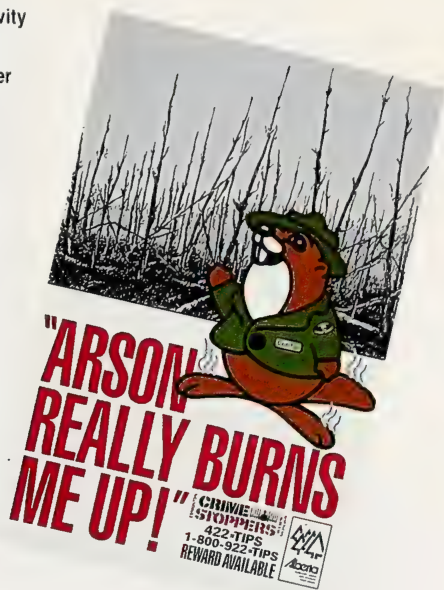

This well-rehearsed quick reaction is backed by a squadron of air tankers and reinforcements of more than 6000 firefighters who are called on to combat any large blazes that are not controlled in the initial response.

Alberta's overall prevention, detection and suppression efforts have had positive results: the number of hectares of forest lost to wildlife is reduced.

The goal is to limit the burned area to less than 0.1 per cent of the protection area each year.

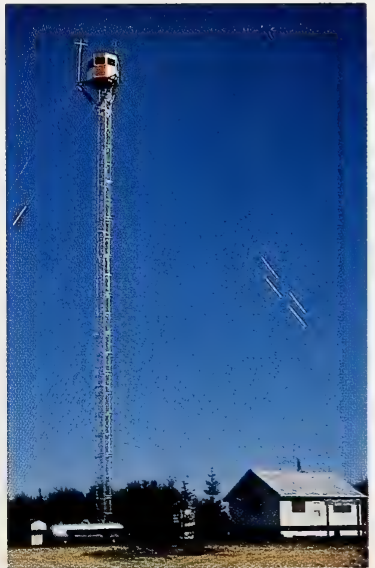

The backbone of Alberta's

forest fire detection system is a network of lookout sites, strategically placed throughout the province. 
When dispatched to a fire,

the air tankers are supervised

by "bird dog" officers in

smaller aircraft who lead the

tankers to the fire and direct

the drops of water or retardant.

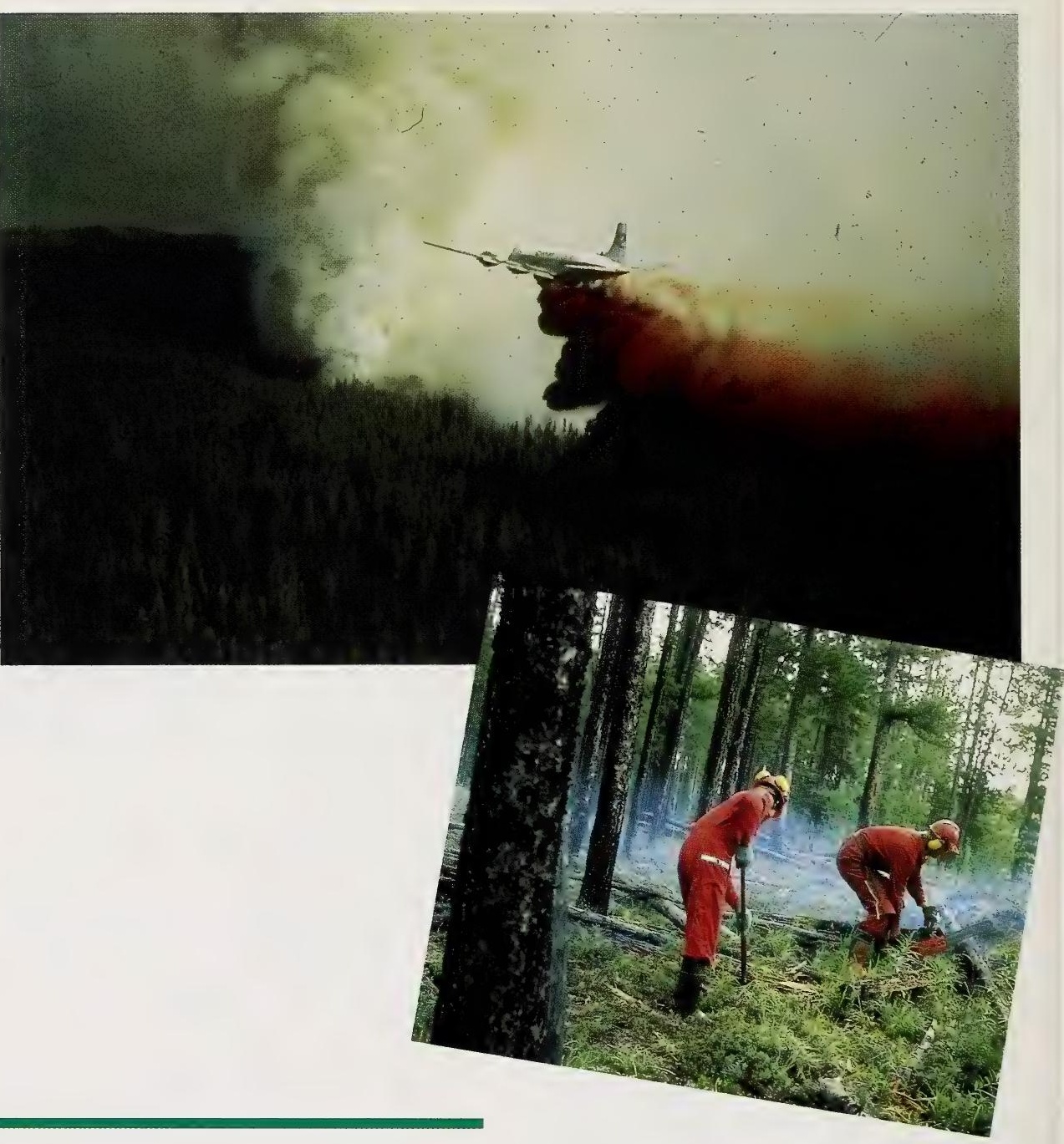

\section{Forest fitness}

The natural ecology of the boreal forest is dictated by wildfire. As a result, most Alberta forests are less than $\mathbf{1 5 0}$ years old. So, although our forest protection activities may change this, currently the term "old growth" forest does not have the same relevance in Alberta as it does in other parts of the world. $\triangle$ Compared to other provinces in Canada, Alberta's forests have had relatively few incidents involving disease and insect pests. Alberta's cool, dry, northern climate is part of the reason for this healthy situation. Our strong commitment to field monitoring and active treatment of problems is another factor. This proactive strategy ensures that potential hazards are discovered and managed before they become uncontrollable. $\Delta$
Fire crews receive intensive

fire suppression training. 


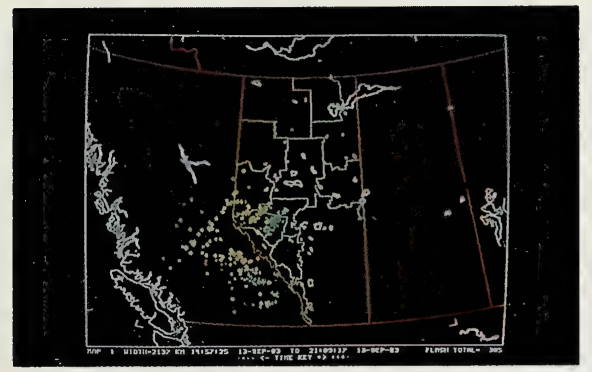

To supplement the

province's lookout network,

Alberta also uses a state-of-

the-art lightning detection

system.

\section{Protecting the forest}

Formal forest protection began in Alberta in 1883 , when a pair of rangers were appointed to the Calgary and Edmonton Timber Agencies by the federal government. These two men, responsible for the southern and northern halves of the province respectively, were charged with the impossible task of monitoring such activities as timber harvesting, while putting out forest fires with the aid of little more than a horse or canoe, an axe and a shovel. $\Delta$ In 1930, the Natural Resources Transfer Act handed ownership of all natural resources to the provincial government. That same year, the Alberta Forest Service came into being, effectively ushering in the modern era of forest management and protection. $\triangle$ Now part of Alberta Forestry, Lands and Wildlife, the Forest Service employs more than $\mathbf{7 0 0}$ people. $\Delta$ Backed by air tankers, helicopters, chemical fire retardants, lightning location systems and infrared scanners, computer graphics and two-way radios, today's rangers are much better equipped than their earlier counterparts. $\Delta$ Another valuable back-up to Alberta's fire detection program is the vigilance of the general public. Every year, a significant number of fires are detected by outdoorsmen, pilots, and other citizens who have obviously taken the message of personal responsibility to heart. To help facilitate such public co-operation, Alberta Forestry, Lands and Wildlife operates 427-FIRE as a year-round, 24-hour hotline.

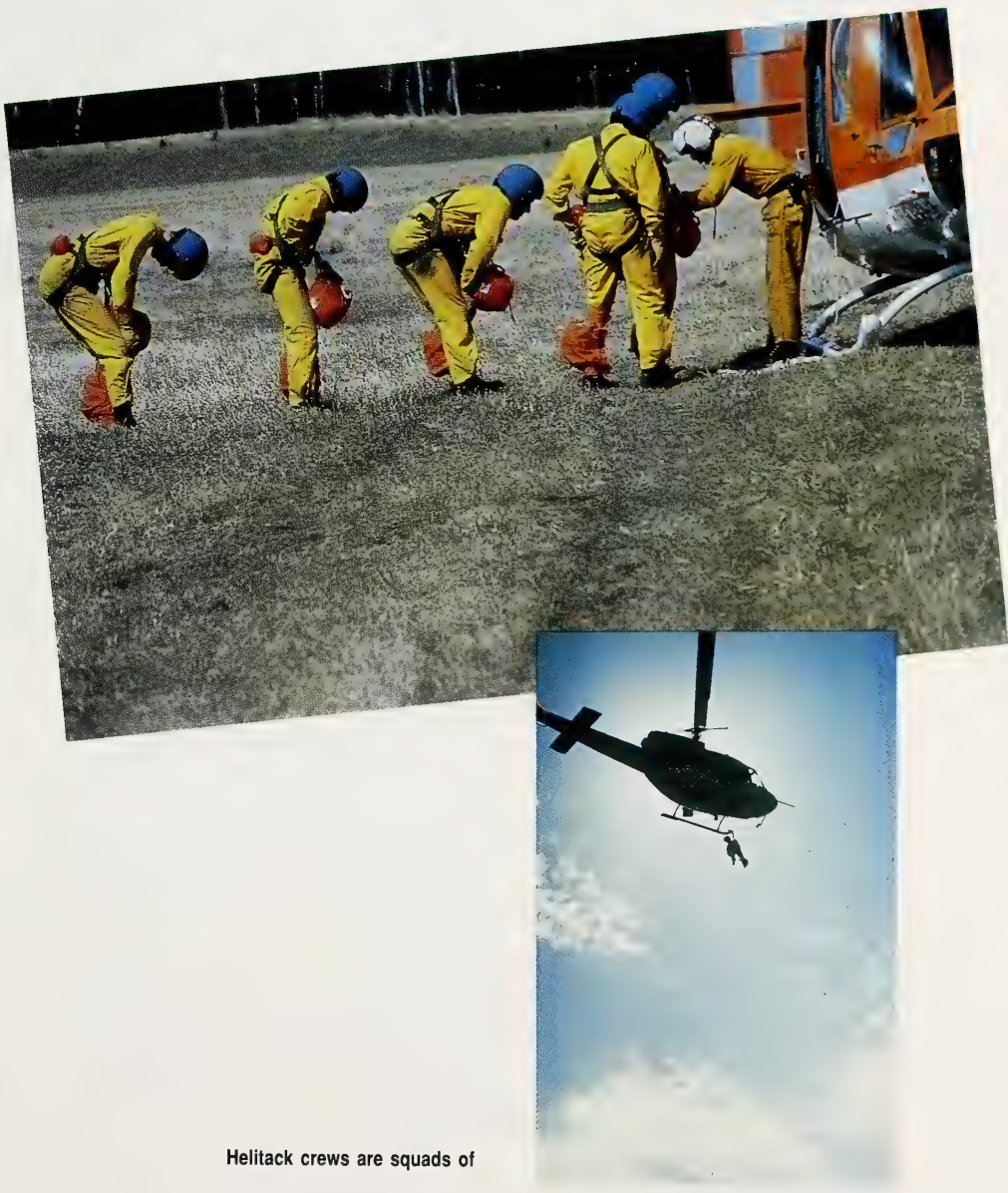

firefighters trained to rappel

down next to a blaze from a

hovering helicopter. 


\section{Timber harvesting and the environment}

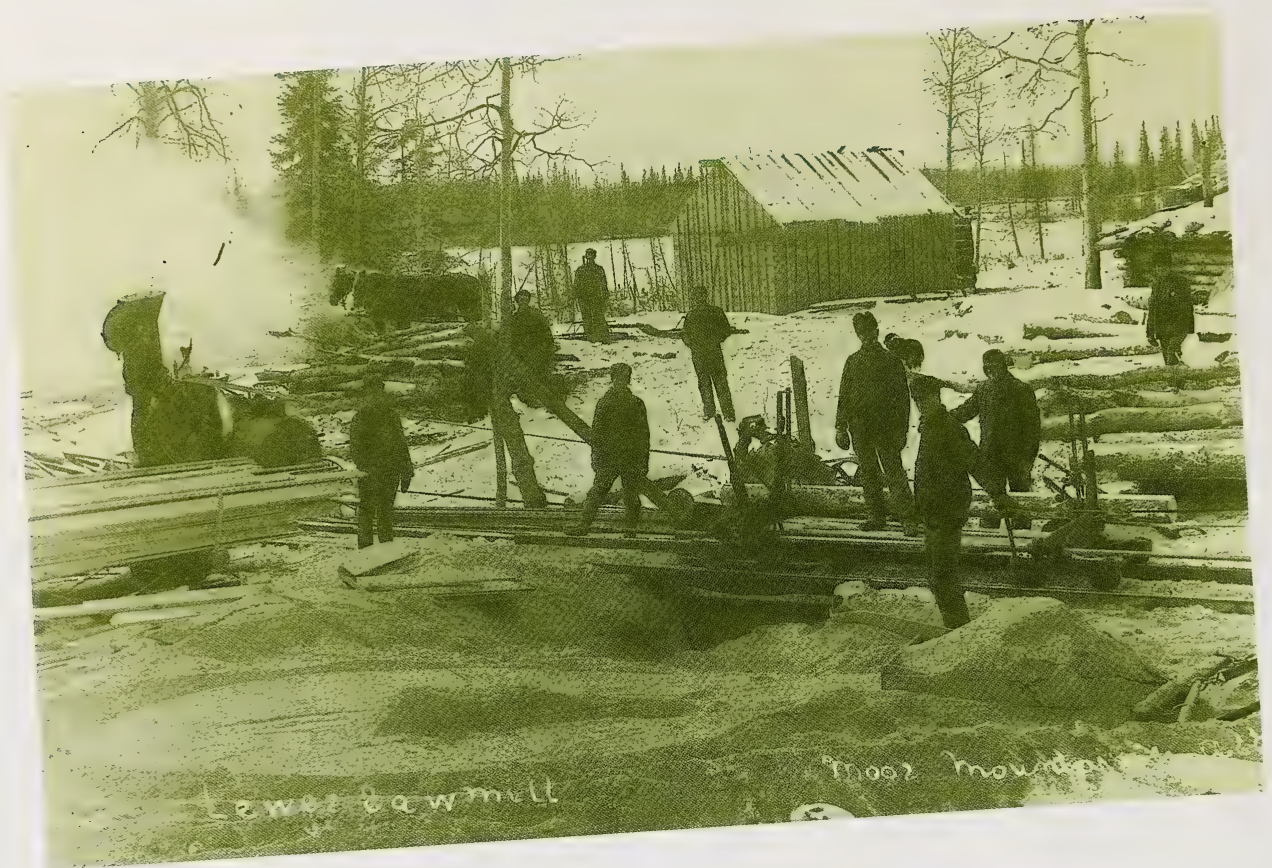

Operational plans must

include provision for the

protection of valuable

watershed areas.

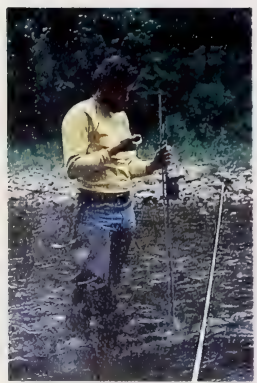

Early loggers cut only the best trees and left the rest. This wasteful practice created an environmental problem as the debris and windtoppled trees attracted insects and disease.

Today Alberta Forestry, Lands and Wildlife has developed, in co-operation with the forest industry and environmental agencies, some of the most effective environmental protection legislation in Canada.

The legislation is based on long-term planning and ongoing monitoring of forest conditions and harvesting techniques.
Integrated resource planning ensures that logging will have minimal impact on the watershed, wildlife and recreational value of the land. Timber harvesting may be prohibited in certain areas set aside for special recreational use, for wildlife, or in areas that are too steep or too close to streams or lakes.

Where timber harvesting is proposed, field data are used to determine how much timber may be cut annually while maintaining requirements for sustainability and environmental protection.

A management plan is developed for the forest area. Resource managers from government and industry, wildlife biologists and, of course, the public, contribute to a mutually acceptable plan for harvesting. 


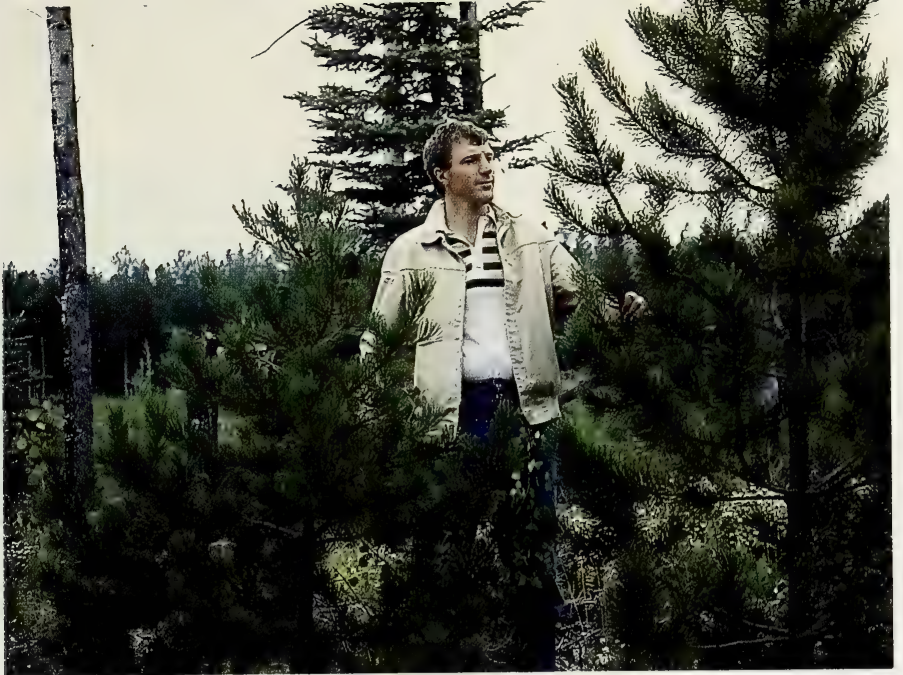

Forest renewal work begins even before the trees are cut down. Built right into approved harvesting plans are reforestation requirements ensuring the amount of timber cut will be equalled or exceeded by new growth. The companies are responsible for the reforestation of the harvested area. Over 25 million seedlings are produced each year at the Pine Ridge Forest Nursery for reforestation, and a major expansion is now under way.

In addition to extensive tree planting programs, forest management in Alberta also takes advantage of natural forest regeneration. Since trees have different ways of releasing seeds, individual harvesting plans must be prepared for each species. For example: long and narrow strips are cut in spruce forests in order to allow the wind to blow new seeds from uncut trees into the cutover areas. In pine forests larger irregular cuts are made, and the seed-bearing cones are left in the cutover areas to encourage natural regeneration. are continuously reviewed and updated to encompass changing conditions and improved technology.
Reforestation requirements

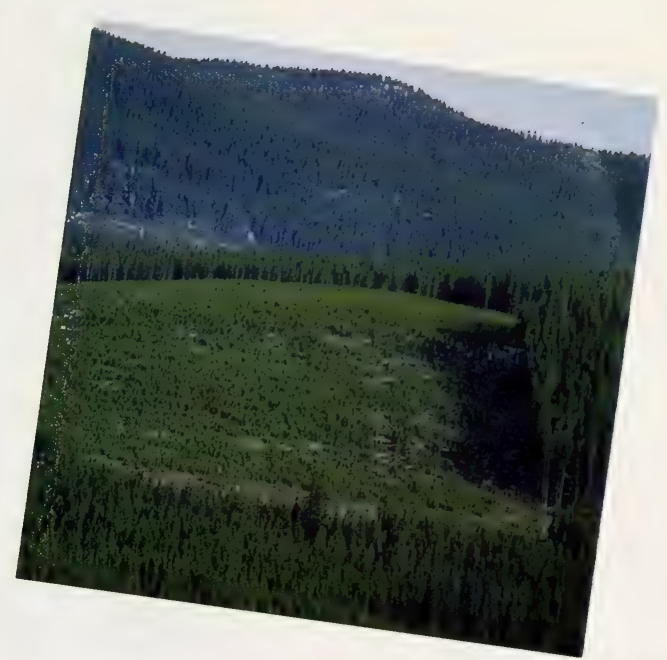

\section{Reforestation}

Reforestation is the most important aspect of forest management activities. There are no "quick fix" solutions for future generations if today's resource is not renewed as it is used. $\Delta$ Alberta's policy of "sustainable development" requires that all users of the forest resource remain committed to a plan for its constant renewal. $\Delta$ Techniques used for reforesting an area not only replace the harvested forest but also may improve upon it. The use of genetically superior tree seedlings leads to stronger, healthier trees. $A$ Proper reforestation has additional benefits of erosion control and improved wildlife habitat. $\Delta$ Reforestation of all cutovers has been required in Alberta since 1966. Alberta Forestry, Lands and Wildlife works closely with industry representatives to establish and maintain specific standards which guarantee the success of reforestation projects. Constant monitoring over a period of years by both government and industry has resulted in reforestation projects consistently meeting or exceeding the established standard for successful forest renewal.

$\Delta$ Careful tending of forests as they grow (through cleaning, thinning and fertilizing) can pay big dividends. Studies have shown intensively managed forests are substantially more productive. $\Delta$ 




16

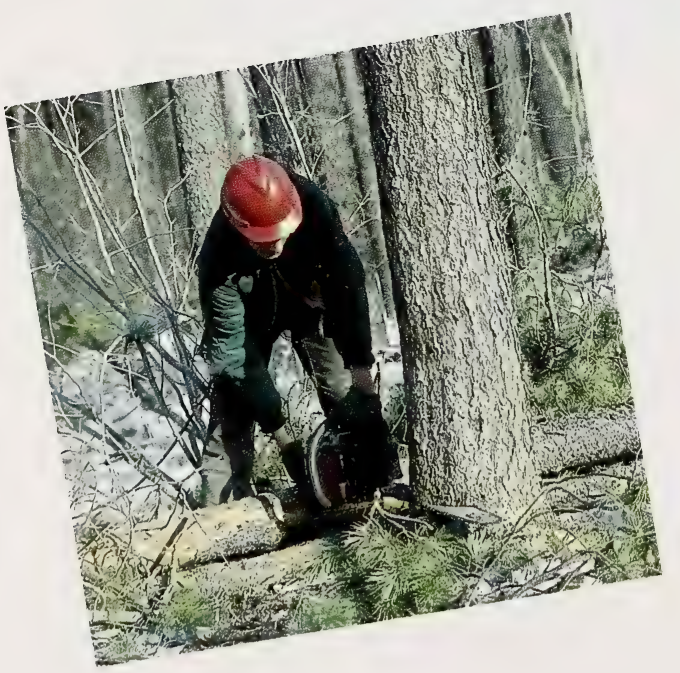

In economic terms,

Alberta's forests mean

billions of dollars in renew-

able income over many

generations.
Forest landscape management guidelines ensure that cutovers are designed to follow the natural slopes and simulate natural forest openings, making them more visually pleasing and beneficial for wildlife.

Without a management and harvesting program, forests can become dense and unsuitable for people and wildlife or, worse, a potential fire hazard. Forest management - which includes timber harvesting - allows for production of the wood products. It also improves habitat for certain species of animals, such as deer and elk, which prefer open areas for feeding.

Timber harvesting can be an effective replacement for the wildfires which, in the past, cleared large areas for grazing land and open wildlife habitat. 


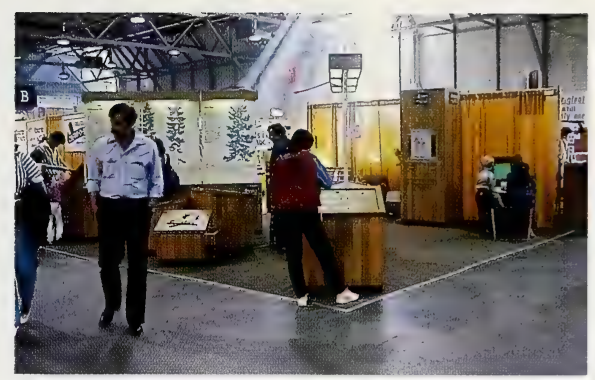

\section{Timber harvesting guidelines}

Periodic independent studies of the forest industry in Alberta have been essential to the development of management programs and legislation. In 1973 a study reported that, while logging practices were environmentally acceptable, there were problems with soil erosion from forestry roads into streams and rivers. Improvements in road building were recommended and included in the government's guidelines for timber harvesting. $\triangle$ In 1978, the Environment Council of Alberta (ECA) initiated a thorough review of forestry operations, holding public hearings across the province at which 188 briefs were presented by individuals, groups and companies. $\triangle$ The ECA study went far beyond traditional environmental impact assessments, and the report issued the following year contained 140 recommendations. Ninety per cent of them have since been implemented. $\triangle$ Many of the recommendations which dealt with the environment have been incorporated

Annual operating plans

submitted by timber

harvesters must comply

with government require-

ments for minimizing impact

on watershed, fish and wild-

life, and recreation directly into the operating ground rules for timber harvesting and the guidelines covering resource roads, stream crossings, watershed assessment and landscape harvesting. $\Delta$ In the 1990 s, a greater public awareness of the importance of the forests and their many benefits to our environment encourages individuals and organizations to get involved. This increasingly active public presence in forest land use decisions means more Albertans are protecting and carefully enjoying our precious forest resources. $\Delta$

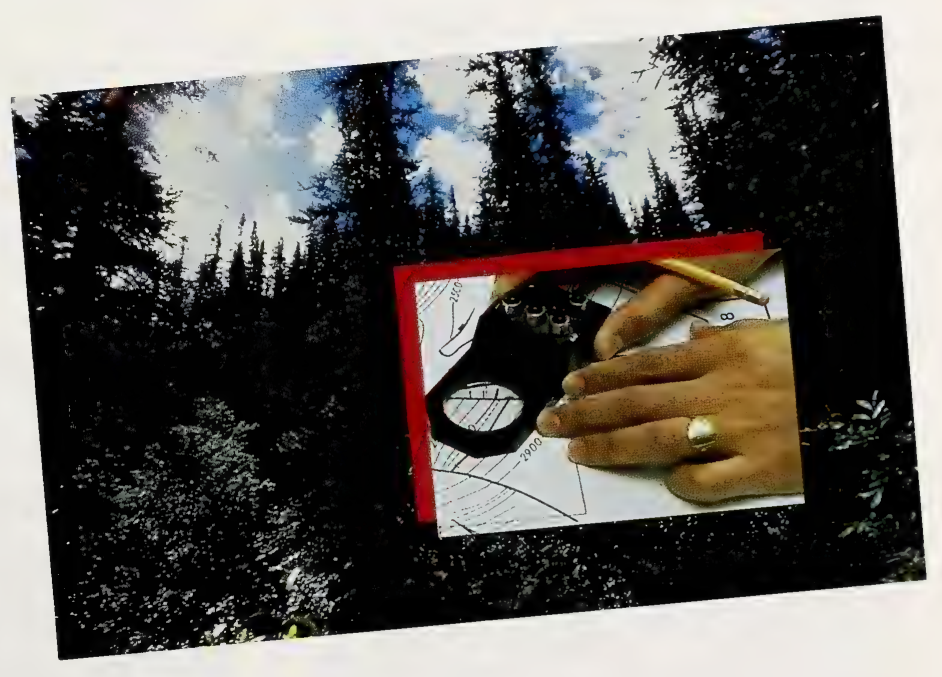




\section{Pine Ridge Forest Nursery}

The trees of tomorrow are getting their start today at the Pine Ridge Forest Nursery.

This state-of-the-art nursery, located near Smoky Lake,145 kilometres northeast of Edmonton, provides high quality seed and seedlings for Alberta's reforestation program.

The Pine Ridge Forest Nursery was built in 1977. The first seedlings were produced there in 1979. By providing better quality planting stock, the nursery strengthens Alberta's forest industry and forest resource. Several private nurseries also provide Alberta forest companies with high quality seedlings to replenish harvested areas.

At the heart of the reforestation process, Pine Ridge Forest Nursery is one of the most modern and complete facilities of its kind in North America. Seedlings grown in one of 20 greenhouses or on one of the $\mathbf{4 5}$ fields surrounding the nursery are destined for use exclusively in Alberta forest renewal projects. Pine Ridge is capable of producing more than 25 million seedlings a year.

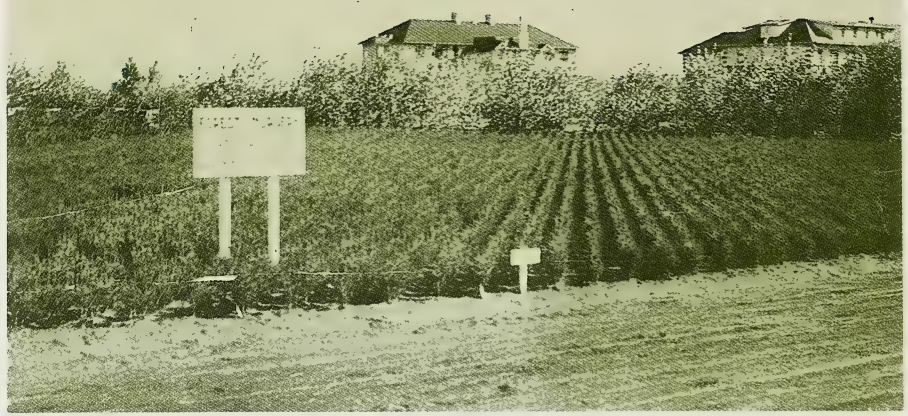

Cones are collected from trees and sent to the nursery by Alberta Forestry, Lands and Wildlife staff and forest industry employees. At the nursery, the seeds are extracted, cleaned, tested and stored until they are returned, as seedlings, to their home region. Research has determined just how far seedlings can be planted from their point of origin and still thrive.

Today, coniferous reforestation is completed almost exclusively with lodgepole pine or white spruce seedlings. Recent experimentation with alternate species may lead to a wider variety of trees in commercial forests.

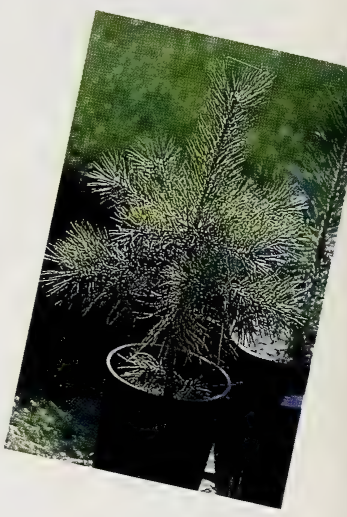

Seedling trees are planted in several research plantations in different growing areas of Alberta.

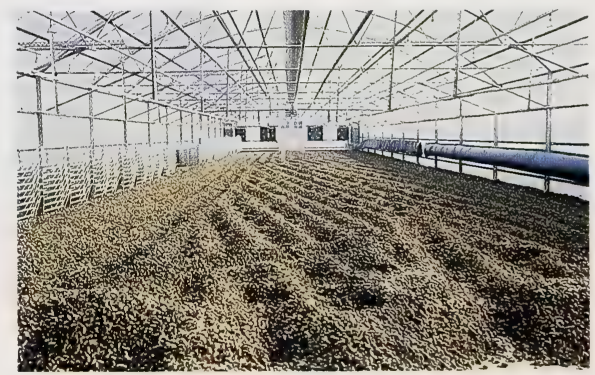

Collecting seeds from cones for artificial seeding and the production of nursery seedlings is an essential part of reforestation. 


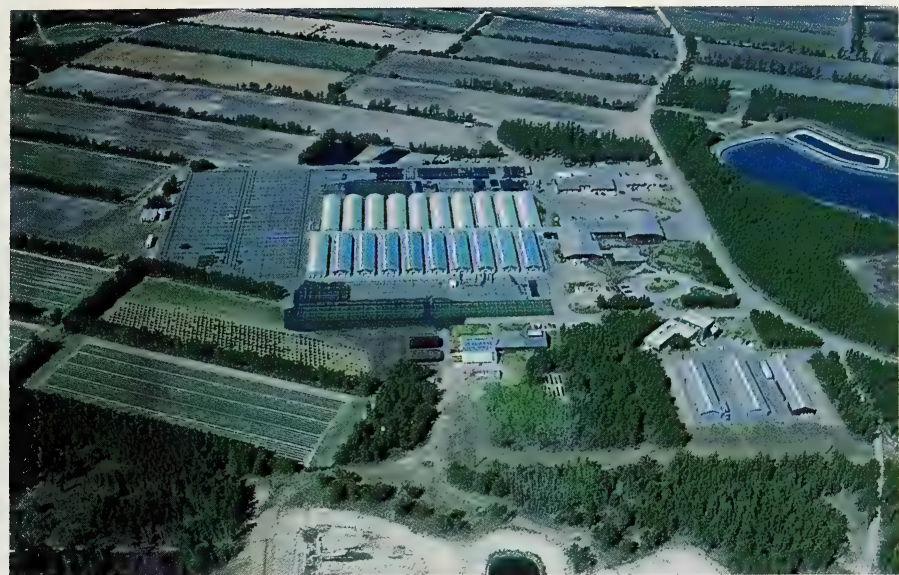

The ability to broaden the variety of our forest species may help increase productivity and minimize damage caused by disease to any one species.

Pine Ridge Forest Nursery is also the centre of most of the provincial genetics program. The program is funded jointly by industry and Alberta Forestry, Lands and Wildlife.

In the Pine Ridge laboratories and fields, genetics researchers test the wood quality and growth characteristics of selected superior trees and perform the delicate task of multiplying these selected individuals. Branches are harvested from the best trees and grafted onto young seedlings, so scientists will have genetic copies of the superior trees to study, plant and breed.
Pine Ridge Forest Nursery is

the major centre for seed

extraction and seedling pro-

duction in the province.

Tree geneticists work with

lodgepole pine and white

spruce as these are currently

the most important commer-

cial species.

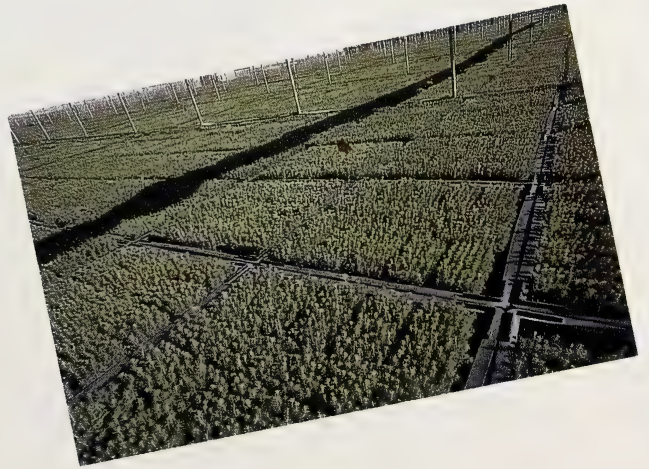

Container seedlings are

germinated in the controlled

atmosphere of a greenhouse.

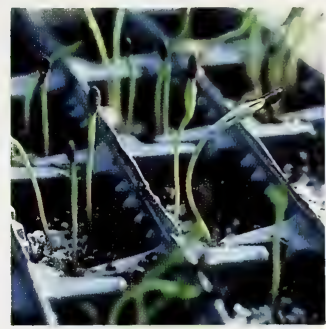

\section{Breeding better trees}

Breeding trees holds great promise for Alberta's forest industry. $\Delta$ A superior tree taller, faster growing, straighter, with fewer branches - is the goal of a tree breeder. $A$ Genetics and tree improvement is a demonstrated way of increasing the growth, resistance to disease, wood quality and the value of the forest. $\Delta$ Alberta's tree breeding research program began in 1976 . Since then almost 1,500 superior trees, mostly lodgepole pine or white spruce, have been selected for the lab and field testing in $\mathbf{3 2}$ areas around the province. $\Delta$ The goal is to have genetically superior trees which are suited to the various growing conditions found in different areas in Alberta. $A$

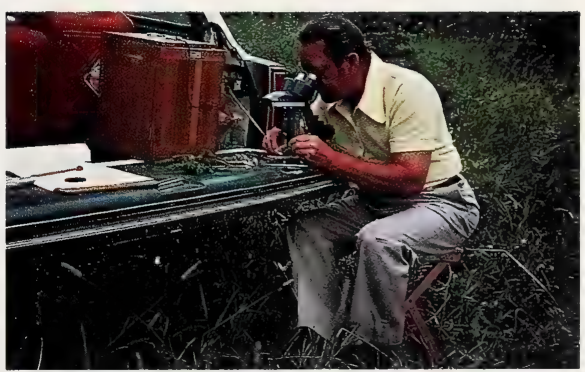




\section{Learning in the forest}

In Alberta, the Junior Forest Warden program is sponsored by Alberta Forestry, Lands and Wildlife and run by adult volunteers. More than 3000 youngsters belong to more than 100 clubs throughout the province.

The purpose of the program is to ensure that the younger generation is informed and concerned about conservation of our wildlands and wildlife resources.

The Junior Forest Warden activities draw young people outdoors where real learning about forests and wildlife can take place. There is a strong emphasis on conservation and on the development of an outdoor ethic. Even the youngest wardens are planting trees every year, participating in nature walks, or involved in projects which teach them the importance of careful forest management.

Participants hike, camp, canoe and snowshoe. Older wardens get a chance to experience wilderness camping and backpacking, rock climbing and whitewater canoeing. These activities help them to understand life in the forest.

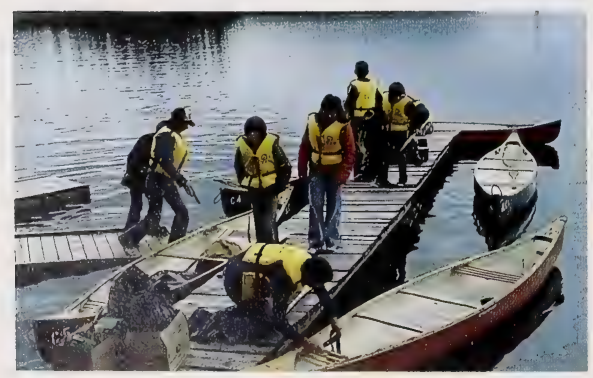

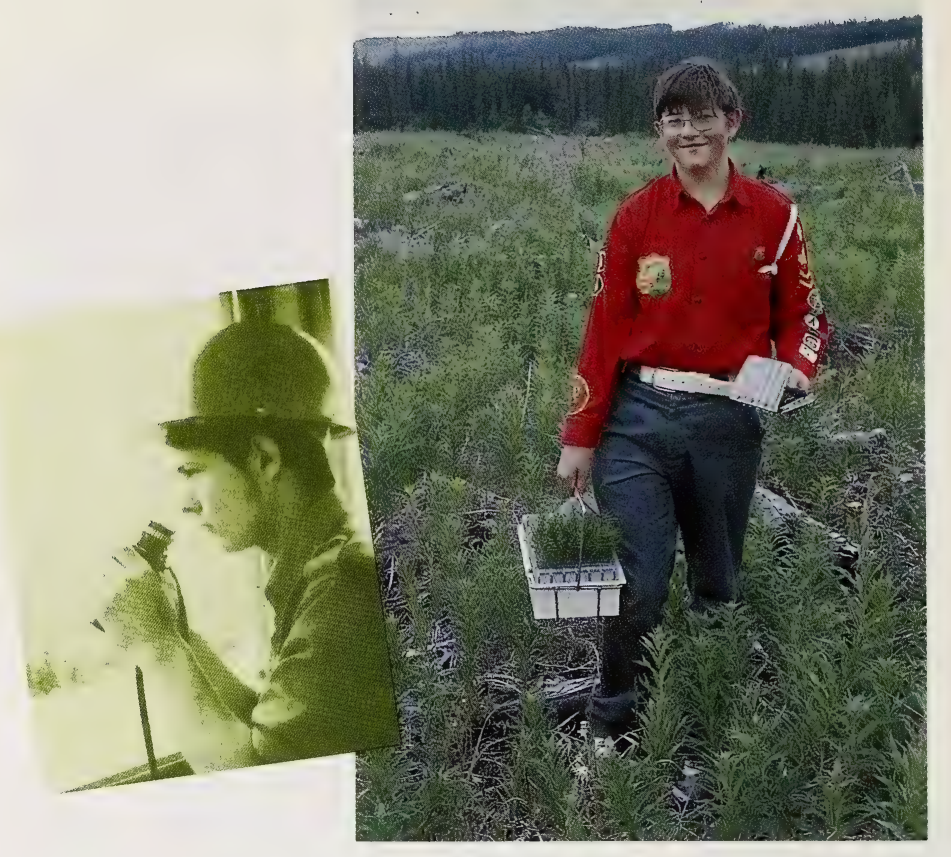

As these young people progress

through the Junior Forest Warden program, they learn a lot about what is involved in a career in forestry or wildlife. Many study for these types of careers later in life.

Alberta's young people have a proud tradition of forest protection.

Junior Forest Wardens of

As public education programs increasingly give young people a broader perspective on Alberta's forests, the all ages are involved in tree planting programs. resource itself will benefit from a better informed, more experienced populace who have the forest's best interests at heart.

Project Wild is a school.

based activity program with

an emphasis on safety and

conservation.

\section{Project Wild \\ Project Wild}

Fish and Wildlife Conservation education programs complement the forestry activities of the Junior Forest Wardens. In addition to teaching about fish and wildlife, these special programs also focus on ethics, safety and conservation. $\Delta$ Project Wild is a school-based activity program to teach children about wildlife habitat and identification, predator/prey relationships, animal behaviour and, ultimately, the importance of wildlife. $\Delta$ Project Wild activity materials are provided for teachers and adult leaders of young people's groups. $\Delta$ The hunting and fishing education programs teach specific techniques and provide information necessary for certification in each area. $\Delta$ 


\section{Junior Forest Rangers}

The Junior Forest Rangers program offers paid summer work experience for young people, 16 to 18 years of age. They live in tent camps and, with supervision, work at tasks such as trail maintenance and tree planting. $\Delta$ Special courses and training programs in forest protection and inventory techniques, mapping and orienteering, and survival and rescue techniques improve the outdoor skills of these young foresters. $\Delta$ The emphasis is on personal growth and leadership skills as well as meaningful outdoor experiences. $\triangle$

Junior Forest Rangers

receive a wide range of

outdoor orientation training

experiences.
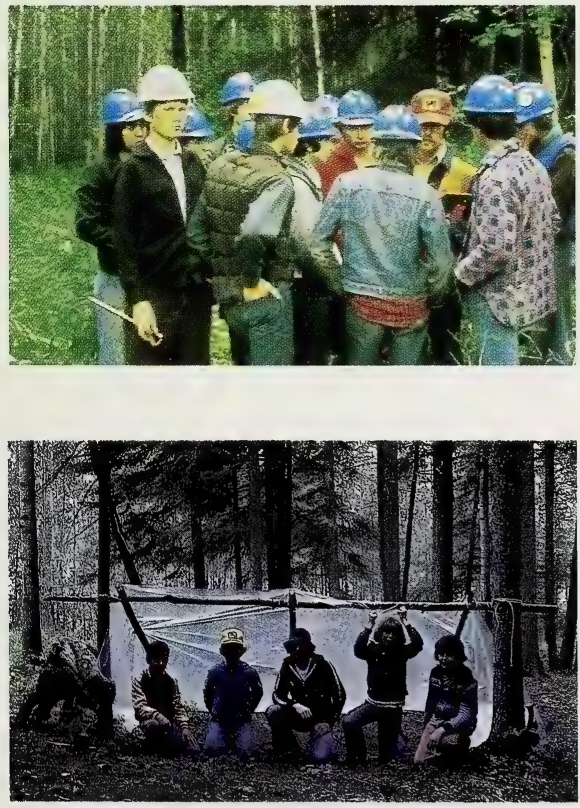

Part of learning about the

forest is being there during

the different seasons.

\section{Alberta Forestry Association}

The forest is a living entity - a complex ecosystem in which the inhabitants are born, live, and die, with new generations coming after to renew the process.

Getting this simple message to Albertans is the basis for the The Alberta Forestry Association (AFA), a team made up of individuals, companies and government, all vitally interested in, and dedicated to, maintaining Alberta's forests as a productive and renewable resource. $\Delta$ The association's major goal is increased public awareness and education. AFA works to bring about a better understanding of the forest among Albertans of all ages and backgrounds. It also serves as a sounding board for public concerns regarding present and future uses of the forest. $\Delta$ The Alberta Forestry Association has a leadership role in developing common objectives and co-operation among: forest environmentalists and conservationists, recreational users, timber harvesters, educators, and government planners and managers of the forest resource. $\triangle$

\section{For more information, contact:}

Alberta Forestry Association Suite 101, Alberta Block 10526 Jasper Avenue Edmonton, Alberta, Canada T5J $1 \mathrm{Z7}$

ฮ (403) 428-7582

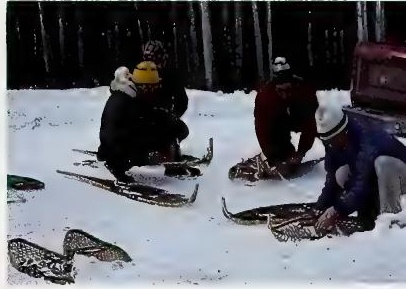

The Alberta Forestry

Association sponsors

forestry awareness programs

for young people. 


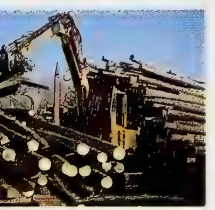

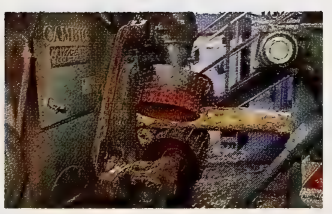

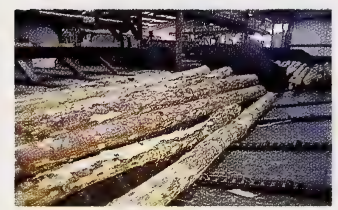

In the past few years, the forest products industry, one of the most rapidly growing sectors in Alberta's economy, has provided direct employment for over 10,000 Albertans.

When the producers of secondary forest products are considered, forestry is the major industry in 54 Alberta communities.

Alberta Forest Products Association inspectors periodically visit Alberta mills to maintain quality standards.
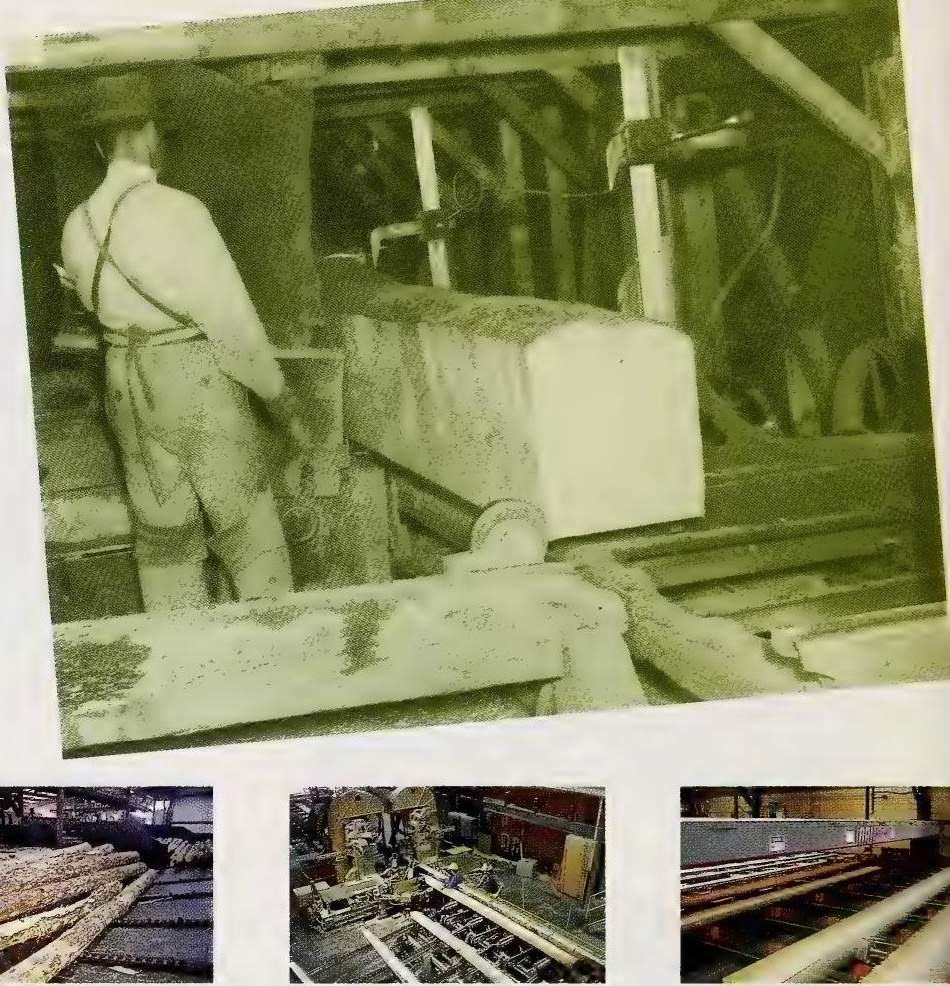

\section{Lumber}

Sawmills produce over 1.7 billion board feet of lumber each year. Most Alberta lumber is made from white spruce or lodgepole pine.

Alberta's northern climate encourages slow growth and produces closegrained, structurally superior trees. The long wood fibres in Alberta's spruce and pine mean strong, lightweight, pliant wood with excellent characteristics for a variety of purposes. Consistent, light-coloured, tight-knotted spruce and pine logs are processed into quality wood products.

Widely used in North America, Alberta lumber is ideal for components of residential homes and commercial buildings. Alberta lumber is also re-manufactured for use as moulding, furniture, panelling and flooring. 
While softwood timber currently dominates the industry, new applications are making native hardwoods, especially aspen (poplar), increasingly desirable. As a result, a growing number of companies are producing aspen lumber.

Most Alberta lumber is kiln-dried to reduce moisture content. This process kills potentially harmful insects or bacteria which may be in the wood. It also reduces the weight of the lumber and cuts transportation costs.

Alberta's low natural gas costs make kiln drying an economical practice and kiln schedules can be regulated to meet specific species and customer needs.

To ensure lumber meets worldwide specifications, stringent quality control guidelines are enforced by certified inspectors of the Alberta Forest Products Association. These independent inspectors visit mills at random, test and make certain graded lumber meets quality standards.

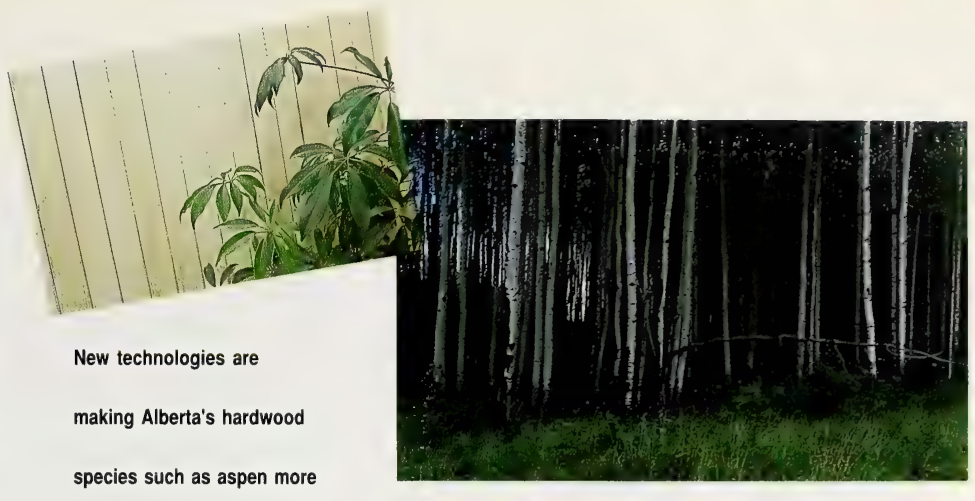

desirable in panelling and

other specialty products.

New pulp and paper mills

proposed for Alberta use the

most advanced technology

in the world.

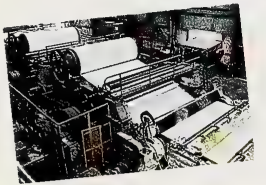

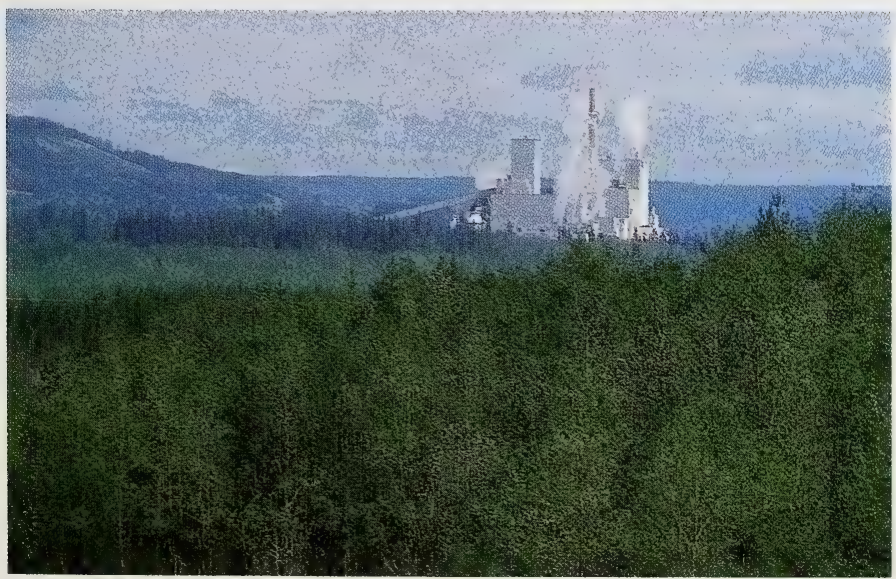

\section{Pulp and paper}

Alberta's well-developed pulp and paper industry produces newsprint and pulp for use in manufacturing a variety of paper products.

Recent growth in this industry has contributed to increased employment and diversification of Alberta's economy. Public and private evaluation and investment continue to ensure that the industry is environmentally sound and sustainable.

In the future, the quality and mix of kraft and mechanical market pulps will contribute to exciting growth in the province's paper manufacturing industry. 


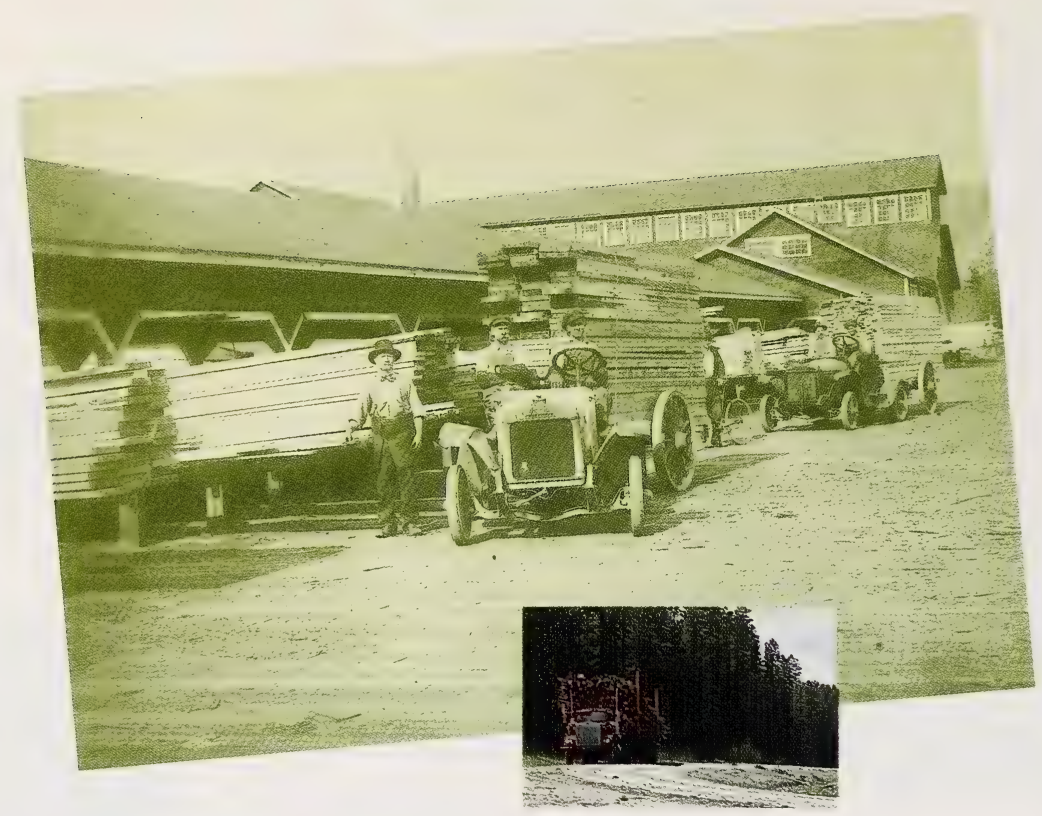

\section{Alberta Forest Product Shippers Association}

The Alberta Forest Products Shippers Association (AFPSA) is a non-profit organization whose major objectives include assisting forest product manufacturers in minimizing transportation costs and co-ordinating the movement of forest products from mills in Alberta to national and international markets. $\Delta$ Membership is open to Alberta mills and re-manufacturers of forest products. Small and large companies alike may join. $\Delta$ Member benefits include reduced transportation rates, improved transportation management, and a more efficient accounting of transportation costs. $\Delta$

For more information, contact:

Alberta Forest Products Shippers

Association

\#103, 11710 Kingsway Avenue

Edmonton, Alberta

T5G OX5

- (403) $455-4471$ or $455-4556$

fax (403) 451-3824
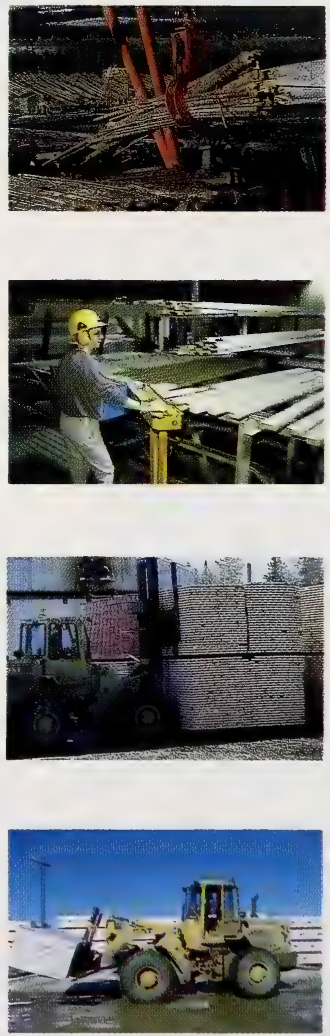

A well-trained and experi-

enced pool of forestry

workers ensures prompt and

professional movement of

product

\section{Panelboard}

Panelboard is highly regarded in many international markets.

White spruce is the main species used in the production of plywood panels. Plywood is used for wall and roof sheathing, sub-flooring and other building components.

Medium-density fibreboard (MDF), is a panel product manufactured from spruce and pine sawmill by-products such as sawdust, shavings and chips.

Combined with a synthetic resin, these materials give MDF physical and finishing properties which make it an attractive alternative to traditional materials in the furniture industry. MDF can be used for furniture, moulding, shelving, countertops, kitchen cabinets, panelling, decking, siding, door core, and roof and wall sheathing. 


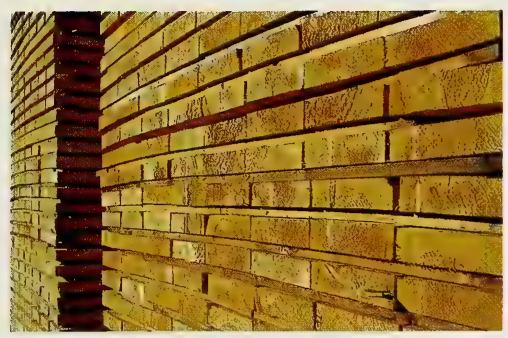

Oriented strandboard (OSB) is one of Alberta's most successful new products. This structural panel is made of long, thin strands of aspen or poplar bonded together under intense heat and pressure with a waterproof phenolic resin.

This rigid, flat exterior panel meets all the performance standards necessary for residential and commercial construction. Building inspectors and builders in many countries find Alberta OSB products excellent for wall and roof sheathing, sub-flooring, pallets and industrial packaging and specialty furniture.

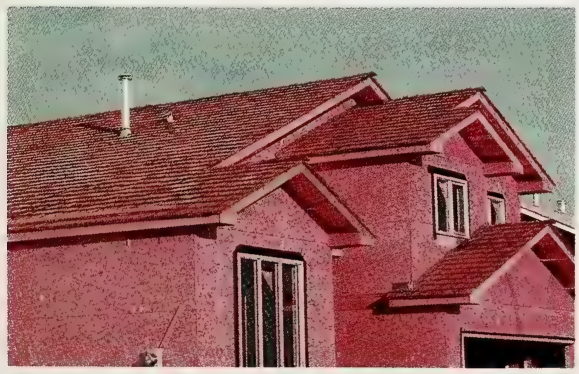

Oriented strandboard, a

relatively new product cur-

rently produced from aspen

(poplar) provides a new

product for a variety of con-

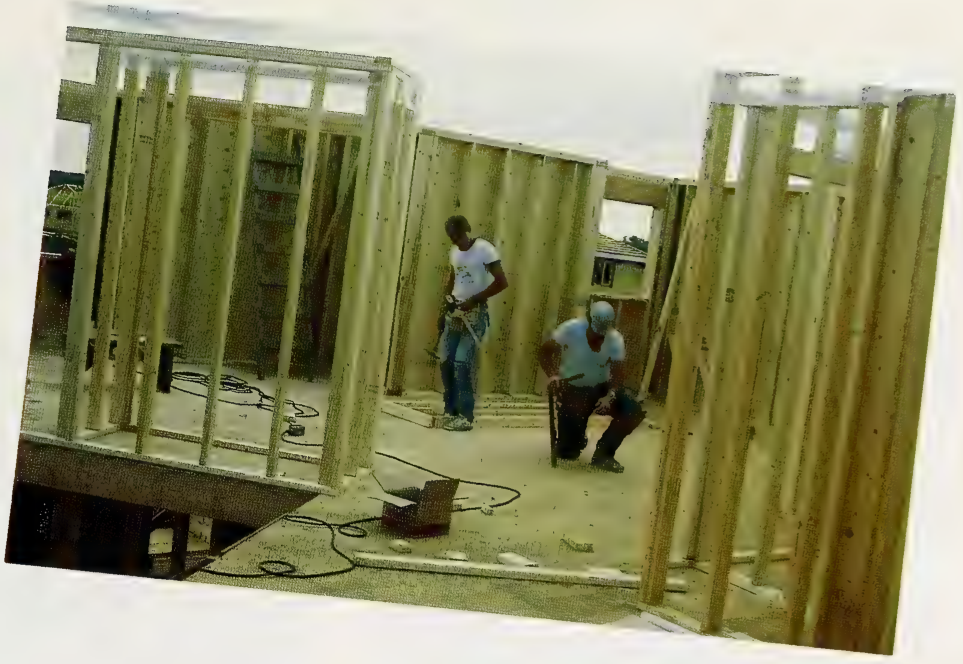

Alberta lumber is used

widely in North America in

the construction of residen-

tial houses and commercia

buildings.

Medium-density fibreboard

(MDF) has uniform texture,

density, and good machining

characteristics and is used

in the furniture and laminat.

ing industries. 


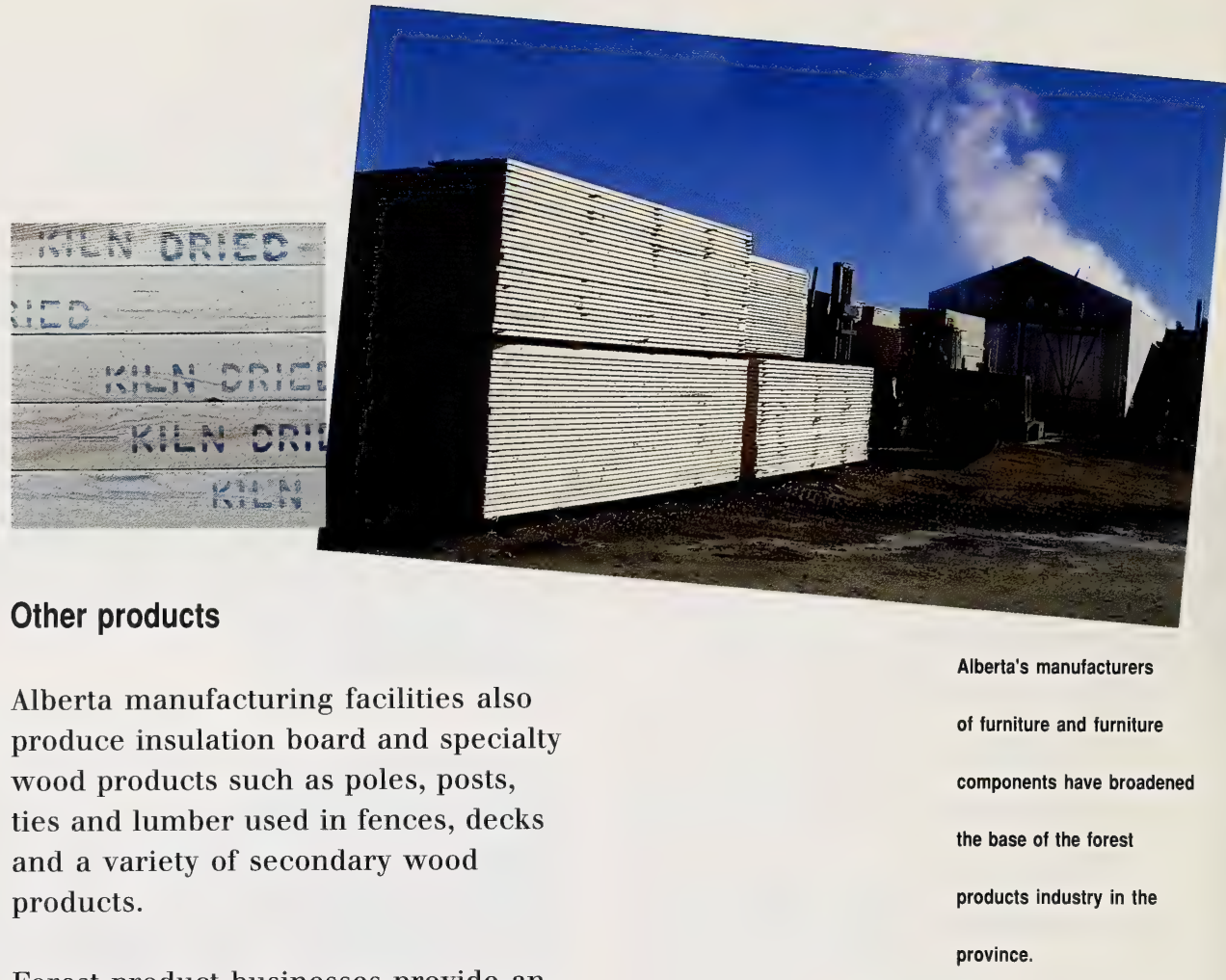

Forest product businesses provide an economic base for growing secondary manufacturing industries in many Alberta communities.

For example, the furniture manufacturing sector is gaining prominence as a source of products for markets in Canada and the United States.

Specialized industries are manufacturing everything from furniture components to paper. The world demand for forest products is increasing and Alberta is positioned to be one of the world's most reliable sources of pulp and paper, lumber, panelboard, and finished wood products.
Industry analysts cite the importance of Alberta's

- high quality resource

- effective forest management

- highly skilled labour force

- well-developed transportation and communications networks

- low energy costs

- on-going research and development

- desire for customer satisfaction,

- high environmental standards as indicators of the province's potential for success in the global forest products market.

Alberta has a strong national and international network of forest product producers, manufacturers and markets.

Responsible forest development and product diversity make Alberta forest products a growing opportunity! 
For more information, contact:

Alberta Forestry, Lands and Wildlife Information Centres
9920 - 108 Street

Main Floor

Edmonton, Alberta, Canada

T5K 2M4

× (403) 427-3590
703 - 6 Avenue SW

Calgary, Alberta, Canada T2P 0T9

× (403) 297-6324

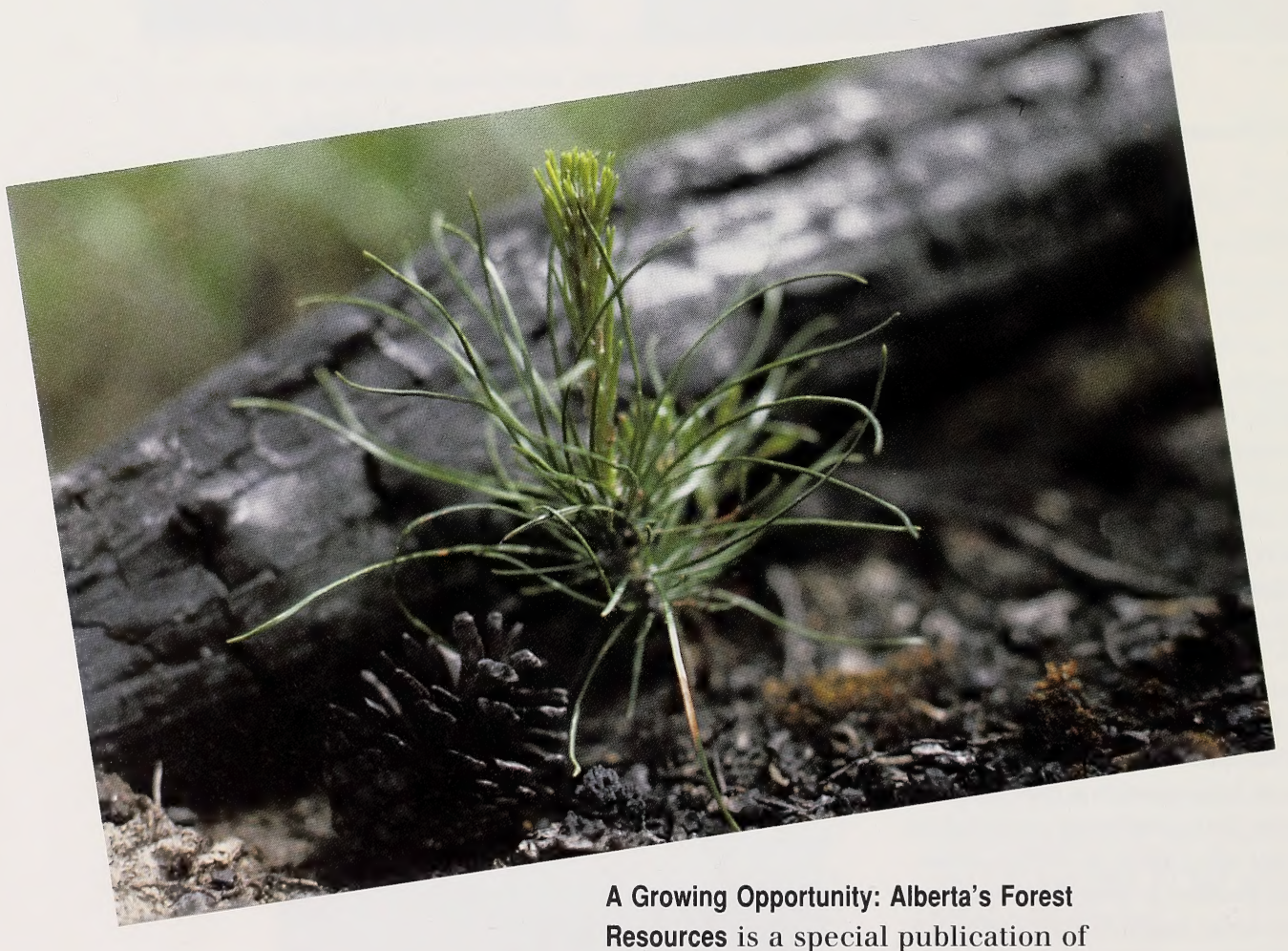

Resources is a special publication of

Alberta Forestry, Lands and Wildlife.

Photos courtesy Government of Alberta, Alberta Research Council, Provincial Archives of Alberta, University of Alberta and Tinsel Media. 

